EUROPEAN CENTRAL BANK

WORKING PAPER SERIES

N0. 348 / APRIL 2004

\title{
FINANCIAL OPENNESS
}

AND GROWTH: SHORT-RUN GAIN, LONG-RUN PAIN?

by Marcel Fratzscher and Matthieu Bussiere

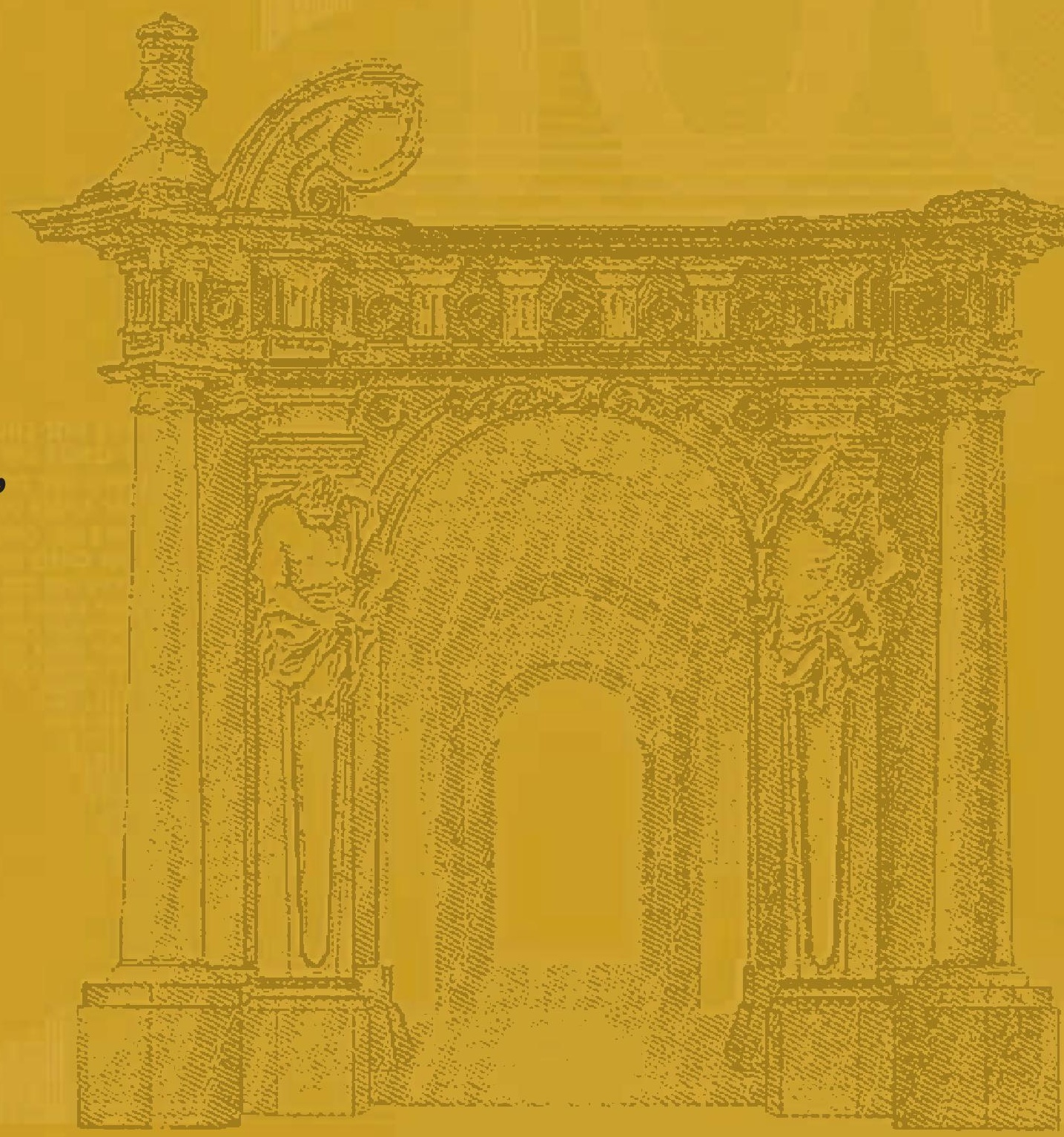




\section{WORKING PAPER SERIES}

N0. 348 / APRIL 2004

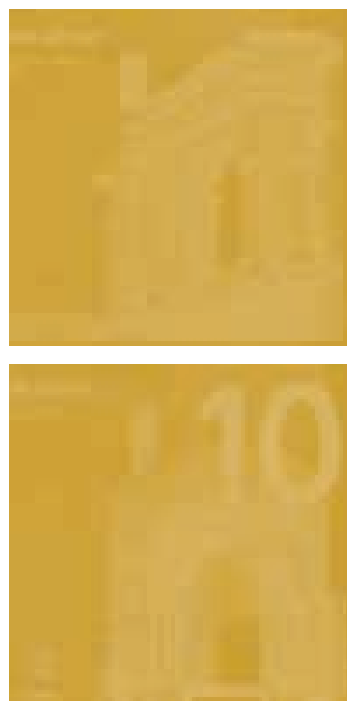

FINANCIAL

OPENNESS

AND GROWTH:

SHORT-RUN GAIN, LONG-RUN PAIN?'

by Marcel Fratzscher ${ }^{2}$ and Matthieu Bussiere ${ }^{3}$

\section{0巨няо}

In 2004 all

publications

will carry

motif taken

$€ 100$ banknote.

This paper can be downloaded without charge from http://www.ecb.int or from the Social Science Research Network electronic library at http://ssrn.com/abstract_id $=533010$. 


\section{드 European Central Bank, 2004}

\section{Address}

Kaiserstrasse 29

60311 Frankfurt am Main, Germany

Postal address

Postfach 160319

60066 Frankfurt am Main, Germany

Telephone

+496913440

\section{Internet}

http://www.ecb.int

Fax

+496913446000

Telex

411144 ecb d

All rights reserved.

Reproduction for educational and noncommercial purposes is permitted provided that the source is acknowledged.

The views expressed in this paper do not necessarily reflect those of the European Central Bank.

The statement of purpose for the ECB Working Paper Series is available from the ECB website, http://www.ecb.int.

ISSN 1561-0810 (print)

ISSN 1725-2806 (online) 


\section{CONTENTS}

Abstract 4

Non-technical summary 5

1 Introduction 7

2 Conceptual issues, data and methodology $\quad 0$

2.1 Measuring financial openness I0

2.2 Data and definitions II

2.3 Empirical methodology $\quad 4$

3 Empirical results 16

3.1 Openness and growth: some stylised facts

3.2 Openness and growth: is there a relationship?

3.3 Which countries benefit from liberalisation?

3.4 The intertemporal trade-off: short-run gain versus long-run pain? 22

3.5 Sensitivity analysis 24

4 Conclusions 28

References $\quad 30$

Appendix 33

European Central Bank working paper series $\quad 34$ 


\begin{abstract}
No empirical evidence has yet emerged for the existence of a robust positive relationship between financial openness and economic growth. This paper argues that a key reason for the elusive evidence is the presence of a time-varying relationship between openness and growth over time: countries tend to gain in the short-term, immediately following capital account liberalisation, but may not grow faster or even experience temporary growth reversals in the medium- to long-term. The paper finds substantial empirical evidence for the existence of such an intertemporal trade-off for 45 industrialised and emerging market economies. The acceleration of growth immediately after liberalisation is found to be often driven by an investment boom and a surge in portfolio and debt inflows. By contrast, the quality of domestic institutions, the size of FDI inflows and the sequencing of the liberalisation process are found to be important driving forces for growth in the medium to longer term.
\end{abstract}

\title{
JEL: F33, F34, F36, F43
}

Keywords: liberalisation; capital account; economic growth; intertemporal trade-off; quality of institutions; composition of capital flows; sequencing. 


\section{Non-technical summary}

The financial crises of the 1990s rekindled the debate on the benefits of financial liberalisation. Economic theory is ambiguous about the relationship between financial openness and economic growth. Models based on the paradigm of competitive and efficient markets tell us that financial openness should foster economic growth and development by improving the allocation of capital. By contrast, others have stressed that the presence of market distortions may lead to welfare reducing effects of financial liberalisation. Such market distortions can take various forms, such as asymmetric information and hidden action (e.g. Stiglitz 1998), or be related to political economy factors (e.g. Bhagwati 1998).

Despite significant research efforts in recent years, the empirical literature is still very much divided on whether financial liberalisation benefits economies, and if so what the necessary prerequisites and conditions are. While some countries have benefited from financial liberalisation, others have not enjoyed higher economic growth or have even experienced severe crises and recessions in the years following liberalisation.

The central hypothesis of the paper is that a key reason for the elusive evidence of a robust openness-growth nexus is the presence of a time-varying relationship between openness and growth over time. This implies that there may be an intertemporal trade-off in that countries tend to gain in the short-term, immediately following capital account liberalisation, but may not grow faster or even experience temporary growth reversals in the medium- to long-term.

The objective and intended contribution of the paper are to test for such an intertemporal trade-off empirically for a broad set of 45 developing and developed economies. Using a standard growth model, the paper starts by comparing open and closed economies and confirms much of the literature's results that open economies indeed do not grow more rapidly than closed ones. Looking at a broad set of potential explanatory factors, it is found that it is in particular the quality of domestic political institutions that play a key role in explaining why some countries benefit from liberalisation whereas others with weaker institutions experience lower growth.

The paper then takes a different angle from the literature and tests for the presence of a timevarying relationship between openness and growth over time. The paper distinguishes between the initial, short-run reaction and the medium- to long-run response of economies to financial liberalisation. It presents evidence that economies indeed tend to receive an initial 
boost and grow faster in the initial five years following financial liberalisation. However, after this short-run gain, economies tend to grow more slowly in the subsequent years. This suggests that there is indeed a trade-off over time, i.e. a short-run gain and a medium/long-run "pain".

More specifically, countries that gain in the initial five-year period after liberalisation are those that experience an investment boom, have large portfolio investment and debt inflows and have larger current account deficits. These findings provide support of the McKinnon-Pill (1997) hypothesis of the presence of an "overborrowing syndrome" after liberalisation. Moreover, it is found that what promotes growth in the medium- to long-term are the quality of institutions as well as the composition of capital inflows. Overall, therefore, the findings imply that the quality of institutions as well as the size and composition of capital inflows are two key determinants for why some countries benefit from financial liberalisation in the medium- to long-run. 


\section{Introduction}

Although economic theory, based on models of competitive and efficient markets, tells us that financial openness should foster economic growth and development, empirical work so far has not found convincing evidence for the existence of such a link. While some countries have benefited from financial liberalisation, others have not enjoyed higher economic growth or have even experienced severe crises and recessions in the years following liberalisation. The counter-argument to those underlining the benefits of liberalisation based on the efficientmarket paradigm has been to stress the presence of market distortions that may lead to welfare reducing effects of financial liberalisation. Such market distortions can take various forms, such as asymmetric information and hidden action (e.g. Stiglitz 1998), or be related to political economy factors (e.g. Bhagwati 1998).

Some recent theoretical work has argued that the main benefits from liberalisation may not come from having access to external capital, but primarily from the fact that the process of opening up leads to a reduction of domestic distortions and locks in reforms (Gourinchas and Jeanne 2002). The recent empirical literature on the issue has investigated a broad set of potential factors and distortions, such as the role of financial depth and development, the quality of domestic institutions, the sequencing of reforms, and the composition of capital inflows. Despite this effort, however, remarkably little consensus has so far been reached about the underlying forces that make financial liberalisation raise economic growth. ${ }^{1}$

This lack of evidence in favour of a robust openness-growth nexus is puzzling in several regards. In particular, an important caveat is that today's most developed economies all have open capital accounts ${ }^{2}$ and liberalised domestic financial sectors. Moreover, those emerging markets and transition countries that have opened up, did so relatively recently, mostly between the late 1980s and the mid-1990s. The key question therefore does not seem to be whether countries benefit from liberalisation in the (very) long-run, but the timing and the circumstances under which they benefit.

A key hypothesis that has received little attention in the empirical literature is that there may be a trade-off over time between openness and growth. The theoretical work by Gourinchas and Jeanne (2002) implies that financial liberalisation yields only a one-off benefit for

${ }^{1}$ See Edison et al. (2002a) and Eichengreen (2002) for recent surveys of this literature. A related literature has emerged that focuses on the link between domestic financial structure and economic growth, which is discussed in detail e.g. in Demirguc-Kunt and Levine (2001). 
economies in the short-term, which subsequently return to their long-term growth path. McKinnon and Pill $(1997,1999)$ argue that, in the short-run, improved access to foreign capital may lead to "overborrowing", i.e. an investment boom, and thus temporarily higher growth. However, this initial bubble may be followed by a severe bust, financial crisis and economic contraction as the boom becomes unsustainable. ${ }^{3}$ Hence countries opening up their financial markets may experience a boom and higher growth in the short-run, followed by a recession and a temporary "bust" in the medium-term, and may reap the full gain from liberalisation only in the very long-run. The theoretical arguments by McKinnon and Pill $(1997,1999)$ therefore imply a short-run gain and either no gain or a medium- to long-run pain from financial liberalisation.

The objective of the paper is to test for such an intertemporal trade-off empirically for a broad set of 45 developed countries and emerging market economies. The paper distinguishes between the initial, short-run reaction and the medium- to long-run response of economies to financial liberalisation. It presents evidence that economies indeed tend to receive an initial boost and grow faster in the initial five years following financial liberalisation. However, after this short-run gain, economies tend to grow more slowly in the subsequent years. This suggests that there is indeed a trade-off over time, i.e. a short-run gain and a medium/long-run "pain". Given that most emerging markets liberalised only within the last decade, an important caveat is, however, that this cost in the medium-term may be only be a temporary one, and that countries may return to faster growth in the long-run, following the experience of most developed economies decades earlier. It therefore may be too early to tell whether developing countries will really gain in the long-run from liberalisation.

The literature has so far given little attention to this potential intertemporal trade-off. Kaminsky and Schmukler (2003) look at a similar trade-off, though not for economic growth but for equity markets. They find that the amplitude of boom-bust cycles in equity markets is higher in the initial period after liberalisation, and that it falls subsequently. In the literature on openness and growth, the work that analyses a related issue is that of Eichengreen and Leblang (2003). They argue that the reason for the lack of evidence for a positive relationship between openness and growth in the literature is its failure to account for financial crises. They indeed find that countries grow faster when controlling for crises. However, the difficulty with this argument is one of endogeneity, i.e. that countries may be experiencing

\footnotetext{
${ }^{2}$ Note that what the paper calls "capital account" refers in fact to the financial account according to the IMF's $5^{\text {th }}$ Balance of Payments Manual. However, the paper sticks to the commonly used terminology.

${ }^{3}$ In McKinnon and Pill $(1997,1999)$, it is moral hazard that induces excessive investment and risktaking as investors are insufficiently supervised and expect to be bailed out if investment projects fail.
} 
severe crises because they have liberalised. Hence, as in the McKinnon-Pill argument, the initial boom in growth may come at the cost of lower growth or recession later on.

Looking at the wider literature on openness and growth, Grilli and Milesi-Ferretti (1995) were among the first who pointed out the lack of a positive effect of capital account liberalisation proxied by the removal of restrictions to capital account transactions as published in the IMF's Annual Report on Exchange Arrangements and Exchange Restrictions (AREAR) - on growth for 61 countries between 1966 and 1989. Rodrik (1998) also fails to find a positive opennessgrowth nexus for close to 100 countries, using a similar openness measure, although his approach is a purely cross-sectional one in which he analyses whether countries that had been open for a relatively longer part of the period 1975-89 also experienced faster economic growth. The findings of these two influential studies stand in sharp contrast to those of Quinn (1997), who develops an original measure of openness, also based on AREAR but allowing for different degrees of openness. He finds that the change in his openness measure is indeed significant in explaining faster real GDP growth for a set of 58 countries in 1960-89.

After the sharp contrast of these findings, most of the recent papers have essentially attempted to verify the robustness of the results using different country samples, openness measures, time periods and empirical methodologies. Eichengreen (2002) points out that a large part of the different results may come from the fact that Quinn's sample includes more industrialised countries and relatively fewer observations of the lost decade of the 1980s. Edwards (2001), Bailliu (2000) and Klein and Olivei (1999) indeed find evidence that openness promotes growth in industrialised countries, although Edwards' (2001) results also reveal that openness tends to hurt growth in developing countries. Arteta, Eichengreen and Wyplosz (2001), by contrast, argue that Edwards' results are sensitive to several exogeneity assumptions and the choice of the empirical methodology. Moreover, they find some positive effect of openness on growth only if countries have stable macroeconomic conditions.

Edison et al. (2002b) also do not detect any strong empirical link between openness and growth although they use a broad variety of different openness measures - both based on the AREAR and on de facto measures of openness - for a broad set of countries and using three different methodologies, two cross-sectional ones based on OLS and IV and one based on a dynamic panel data model using GMM. Finally, Bekaert, Harvey and Lundblad (2001) analyse a different type of openness by looking at the effects of stock market liberalisation on growth in a panel framework. They find that equity market liberalisation leads to a $1 \%$ increase in annual GDP growth during the five years after liberalisation. 
The intended contribution of this paper is to take a different angle from the literature and to test for the presence of a time-varying relationship between openness and growth over time, i.e. the presence of an intertemporal trade-off between growth and financial liberalisation. Using a standard growth model, the paper starts by comparing open and closed economies and confirms much of the literature's results that open economies indeed do not grow more rapidly than closed ones. Looking at a broad set of potential explanatory factors, it is found that it is in particular the quality of domestic political institutions that play a key role in explaining why some countries benefit from liberalisation whereas others with weaker institutions experience lower growth.

Analysing the intertemporal trade-off, it is found that countries indeed tend to grow more quickly immediately after liberalisation and slower in the medium-term. More specifically, countries that gain in the initial five-year period after liberalisation are those that experience an investment boom, have large portfolio investment and debt inflows and have larger current account deficits. These findings provide support of the McKinnon-Pill hypothesis of the presence of an "overborrowing syndrome" after liberalisation. Moreover, it is found that what promotes growth in the medium- to long-term are the quality of institutions as well as the composition of capital inflows. Overall, therefore, the findings imply that the quality of institutions as well as the size and composition of capital inflows are two key determinants for why some countries benefit from financial liberalisation in the medium- to long-run.

The paper proceeds as follows. Section 2 outlines some key conceptual and data issues. The section includes a discussion of alternative openness measures used in the literature, and in this paper, for quantifying financial openness. Moreover, the country sample, data and variable definitions and the empirical methodology are discussed. Section 3 then presents the empirical findings, first starting with a comparison of open versus closed economies. The final parts of the section then show and discuss the findings for the intertemporal trade-off of financial openness for the sample of 45 countries. Section 4 provides conclusions and discusses some policy implications.

\section{Conceptual issues, data and methodology}

\subsection{Measuring financial openness}

A key conceptual issue is the question of how to measure capital account openness. Two broad approaches can be found in the literature: one based on measuring de jure openness, and one measuring de facto openness. De jure openness is mostly proxied by the removal of 
restrictions to capital account transactions as published in line E.2 of the IMF's AREAR, although also the OECD Code of Liberalisation of Capital Movements has similar information, albeit only for OECD countries. The AREAR measure has been utilised in different forms in the literature. The usual way is to simply define it as a discrete $0-1$ variable, i.e. indicating full openness or closedness. Studies using longer time periods, such as e.g. 5year periods, generally use the share of the years in which a country had an open capital account as the measure of openness. The advantage of these measures is that they allow for a clear and easy identification of when a country had removed all barriers to capital account transactions. However, a drawback is that countries may liberalise their capital accounts by removing individual barriers gradually over time. ${ }^{4}$

As an alternative, Quinn (1997) exploits the details of the descriptions in the AREAR to construct an openness measure which can take 9 different degrees of openness - from 0 to 4 in 0.5 point increments. This allows for a much finer categorisation of de jure openness and its changes. However, a key drawbacks is that this openness measure has been created only for four years - 1958, 1973, 1982 and 1988 - thus not allowing the identification of in which years a country undertook those changes.

As an alternative to these de jure measures, the literature has analysed various de facto proxies of openness. The rationale for looking at actual openness is that a country that is open de jure may not necessarily experience such inflows. Since the question of interest is whether capital flows benefit or hurt countries, one may argue that one should define openness in terms of both legal restrictions and actual capital flows. The literature has looked at various capital flows as related to FDI, portfolio flows and debt flows (e.g. Kraay 1998).

Moreover, what may matter for whether countries grow faster or slower may not be the flows per se, but the stock (cumulated flows) of foreign capital into the countries. Some work therefore builds on the pioneering work by Lane and Milesi-Ferretti (2001) and employs net foreign asset positions to capture a country's capital stock (e.g. Edison et al. 2002b). However, in addition to measurement difficulties, one problem with using actual capital flow or stock data is that there may be a non-linear relationship between the magnitude of capital flows and economic performance: countries may benefit from modest inflows, but may not do so if capital inflows become very large, and they may gain if they take some forms, such as FDI, rather than others.

\footnotetext{
${ }^{4}$ Related measures of openness, but for domestic equity markets and not capital accounts, have been developed by Bekaert and Harvey (1995), Levine and Zervos (1998), Bekaert, Harvey and Lundblad (2001) and Edison and Warnock (2002).
} 
One key difficulty of analysing the link between financial openness and growth is that the opening process may not be purely exogenous, or at least may be correlated with other developments in the economy. This problem may be particularly acute for the de facto openness measures because actual capital inflows are likely to be at least in part the response of investors to such factors as investment opportunities, the economic and political environment etc. This potential problem should be less serious for the de jure measure as this refers to a usually one-off decision to abolish legal restrictions. ${ }^{5}$

In essence, therefore, the link between de jure openness and growth versus the relationship between de facto openness and growth can contain two quite distinct questions. From a policy perspective, both questions are clearly of significant importance. The first leads to the issue of whether, when and how government should remove barriers to capital account transactions. The second question requires policy-makers to decide, given that legal barriers have been removed, how best to "manage" capital flows, i.e. what the desired magnitude, composition, maturity etc. are. This paper attempts to analyse the role both of de jure and of de facto openness, though its emphasis is on the former.

\subsection{Data and definitions}

The paper analyses the openness-growth nexus for a set of 45 developed countries and emerging market economies: 11 OECD, 12 Asian, 8 Latin American, 9 European Union (EU) acceding countries ${ }^{6}$, plus Bulgaria, Romania, Russia, South Africa and Turkey. The time period analysed is from 1980 to 2002. Many of the 45 countries opened up their capital accounts between 1985 and 1995, while most of the OECD countries in the sample liberalised in the 1960s and 1970s. Thus the important point by Eichengreen (2002) that the results tend to be sensitive to the chosen country sample also applies to this set of countries, although a sensitivity analysis is conducted in the empirical part below. Thus, our sample includes relatively homogeneous countries and excludes in particular Least Developed Economies (LDCs), partly for data availability reasons, but also because the trade-off issue analysed in this paper arises only for countries with a relatively more mature financial system.

For the de jure measure of capital account openness, the paper mostly uses the data from Kaminsky and Schmukler (2003). The Kaminsky-Schmukler dataset allows distinguishing

\footnotetext{
${ }^{5}$ In a few cases, such as in Latin America in the early 1980s and Malaysia temporarily in 1998-99, governments decided to reverse the liberalization and close their capital account. However, these cases are rare, as shown by Olivei and Klein (1999). This could be interpreted as a sign that the political decision to liberalize is exogenous: otherwise, economic crises would lead to liberalization reversals more often.

${ }^{6}$ Only Malta is not included due to data availability.
} 
between three degrees of openness, i.e. between "partially liberalised", "fully liberalised" and "closed" regimes. Moreover, they create similar measures for the openness of domestic equity markets and domestic financial markets for 28 countries for the period 1973-99. Most of their data is based on the IMF's AREAR. What is missing from their dataset, however, are in particular the acceding countries. This paper adds these countries by using information from the EBRD's annual transition reports. Due to the transition process from communist systems, these countries are included only starting in the early to mid-1990s.

For the de facto openness measures, following Edison et al. (2002b) and Kraay (1998), the paper looks at seven different flow variables, four based on FDI and portfolio flows combined FDI and portfolio net flows, combined FDI and portfolio inflows, FDI inflows, portfolio inflows - two proxies related to the size and composition of foreign debt - total foreign debt, and short-term foreign debt - and trade openness - defined as the sum of exports and imports. Moreover two proxies are employed for stock variables - combined FDI and portfolio net stocks, combined FDI and portfolio in-stocks. Net flows and stocks refer to the difference between the asset and liabilities sides of the balance of payments (b.o.p.) in a particular period. ${ }^{7}$

Stocks are defined as cumulated flows, starting mostly in 1980s, where available. This measure of the capital stock held by foreigners is clearly a very imperfect one given that it does not exploit information about the existing capital stock at the beginning of the period and also ignores valuation changes to the net international investment positions (i.i.p.). However, the available dataset on net foreign assets by Lane and Milesi-Ferretti (2001) does not include several of the countries and periods covered by the paper.

Looking at the different flow variables allows analysing the role of the composition of capital flows, while the liberalisation of different segments and markets in the Kaminsky-Schmukler dataset enables testing for the importance of the sequencing of liberalisation.

In order to check for the relevance of the quality of institutions, the paper utilises the rich database of International Country Risk Guide (ICRG) on various political country characteristics, in particular on the quality of the bureaucracy, corruption, democratic accountability, government stability, law and order and socio-economic conditions. This data is available from 1980 to 2002 on a monthly basis. The paper is the first one in the literature to analyse these factors in detail. Chinn and Ito (2002) also investigate the issue, but their

\footnotetext{
${ }^{7}$ All measures are calculated as a percentage of GDP in a given country and given year, see Appendix.
} 
focus is more on legal restrictions, such as creditor rights and protection, transparency of accounting reports, and other micro measures, based largely on the seminal work by La Porta et al. (1998).

Finally, to test also for the role of macroeconomic conditions, the empirical section looks at various macroeconomic indicators - current account and trade balances, private consumption and private investment, per capita income as a proxy for the stage of development a country has reached, government expenditure and inflation. Many of these measures have been utilised in the literature (e.g. Arteta, Eichengreen and Wyplosz 2001) and are measured as ratios relative to GDP.

\subsection{Empirical methodology}

The starting point of the empirical modelling is a simple growth model that is standard in the literature (e.g. Barro and Sala-i-Martin 1995). The dependent variable is the growth rate of real per capita GDP. The control variables are the log of real per capita income at the beginning of the period, the investment to GDP ratio, the population growth rate, as well as government expenditure as a ratio of GDP. The paper follows the modelling strategy of the great majority of studies in the literature and uses this model as benchmark. Subsequently, other variables of interest and interaction terms are added to the benchmark model, so that the variables of the benchmark model stay in the model but are complemented by other variables of interest. The objective is to evaluate the marginal effect of the capital account variables on output growth, controlling for other possible determinants.

The paper employs a dynamic panel-data approach, which allows us to exploit both the within and the between information of the data. We use 5-year averages of the variables to reduce the volatility and to avoid the drawback of having strong cyclical factors in the data. A number of papers in the literature use the same or a very similar approach (e.g. Edison et al. 2002b, Eichengreen and Leblang 2003, Bekaert et al. 2001). This transformation entails that for the 45 countries mostly five 5-year periods exist (1980-84, 1985-89, 1990-94, 1995-99, 2000-02), though Central and Eastern European countries are only included starting in the 1990s. The openness measure is a dummy variable that takes the value of one if a country's capital account was open for the majority of the 5-year period and zero otherwise. Several sensitivity checks have been conducted, and showed that the results were robust to altering the specification by e.g. including instead the share of the years a country was open during a period. 
As to the estimation technique, one option is to use a fixed-effects estimator, which allows for country idiosyncratic effects. The autocorrelation and persistence in the data, however, requires a dynamic estimation of the model. The problem with the fixed-effects estimator is that the dynamic transformation is likely to introduce an inconsistency of the estimator for models with few time series observations and a large number of cross-sectional observations (see Nickell 1981). This is likely to be the case for this model since $\mathrm{T}=5$ and $\mathrm{N}=45$.

The estimation technique used instead is the GMM estimator introduced by Arellano and Bond (1991). This GMM estimator is a dynamic one that estimates the model in first differences and uses lagged values of the variables as instruments. The starting point is a standard specification in levels, where the real per capita growth rate $\mathrm{y}_{\mathrm{i}, \mathrm{t}}$ is persistent, i.e. it is a function of its own past values. The model includes a set of independent variables $X_{i, t}$, which are assumed to be weakly exogenous, and a country fixed effect $\mu_{\mathrm{i}}$

$$
y_{i, t}=\tau y_{i, t-1}+\gamma X_{i, t}+\varepsilon_{i, t}+\mu_{i}
$$

After taking first differences, the previous equation yields:

$$
\Delta y_{i, t}=\tau \Delta y_{i, t-1}+\gamma \Delta X_{i, t}+\Delta \varepsilon_{i, t}
$$

One result of the transformation is that all variables that are time-invariant, such as the country fixed effects, drop out from the model. A key problem with the model of equation (2) is the potential endogeneity of the control variables as well as the correlation between the lagged dependent variable $\mathrm{y}_{\mathrm{i}, \mathrm{t}-1}$ and the error term $\Delta \varepsilon_{\mathrm{i}, \mathrm{t}}$. This problem can be solved by using higher-order lags of $\mathrm{y}_{\mathrm{i}, \mathrm{t}-\mathrm{1}}$ as instruments for $\mathrm{y}_{\mathrm{i}, \mathrm{t}-\mathrm{1}}$. For the GMM estimator to yield unbiased and consistent estimators requires the validity of the moment conditions

$$
E\left[\Delta \varepsilon_{i, t} y_{t-k}\right]=E\left[\Delta \varepsilon_{i, t} X_{t-k}\right]=0 \quad \forall k>1
$$

To keep a sensible relationship between the number of cross-sectional observations and the number of overidentifying restrictions, only one lag of the dependent variable is used as instrument. This implies that $E\left[\Delta \varepsilon_{i, t} y_{t-2}\right]=0$ for each of the five time series observations, so that there are four overidentifying restrictions (5 identifying restrictions, and one to identify $\tau$ ). The validity of these restrictions can then be tested via a Sargan test, using a $\chi^{2}$ distribution with four degrees of freedom. 


\section{Empirical results}

\subsection{Openness and growth: Some stylised facts}

As a starting point, it is useful to look at some stylised facts for various macroeconomic and institutional variables around the time of capital account liberalisation. For this purpose, this sub-section provides an event study, which is shown in Figure 1. The charts show the evolution of key economic variables in the ten years preceding and following liberalisation as an average over all countries in the sample. The choice of the variables presented is motivated by the choice of the variables in the econometric analysis of the subsequent sections.

A first interesting stylised fact is that real per capita GDP growth in the sample of 45 countries indeed increased immediately following liberalisation - indicated by period $\mathrm{t}=0$ in the figures - but then falls back roughly to its pre-liberalisation levels thereafter. Second, the investment to GDP ratio undergoes a similar trend as the growth rate. Third, concerning capital flow variables, portfolio inflows and short-term debt inflows seem to accelerate relatively quickly after liberalisation. By contrast, FDI inflows rise more gradually over time.

Fourth, in terms of liberalisation of domestic equity markets and financial markets - a point related to the sequencing of reforms analysed in more detail in section 3.5 below - an important stylised fact is that about $40 \%$ of the countries had liberalised either their domestic financial markets, their domestic equity markets or both prior to opening up their capital account. ${ }^{8}$ The other countries liberalised these markets either roughly simultaneously or later than the capital account. Finally, the ICRG total composite index and the political risk index improve significantly in the years before and after liberalisation. ${ }^{9}$

A final noteworthy point is that the divergence of the variables - shown by the standard deviations in the figures - is not only relatively large, but mostly increases significantly after liberalisation. This rise is particularly strong for the capital flow variables. Overall, these stylised facts show some interesting results. But they also underline that despite some marked differences between the pre-liberalisation and post-liberalisation periods, as well as between the short-term versus long-term post-liberalisation periods, one cannot readily draw a clearcut conclusion about the link between openness and growth. The aim of the econometric analysis is to carefully disentangle these effects.

\footnotetext{
${ }^{8}$ For these variables, the y-axis shows the percentage share of all countries that had liberalized at any one point in time.

${ }^{9}$ Note that a higher measure for the institutional variables implies an improvement in institutions.
} 
Figures 1: Event study - Macroeconomic and institutions variables
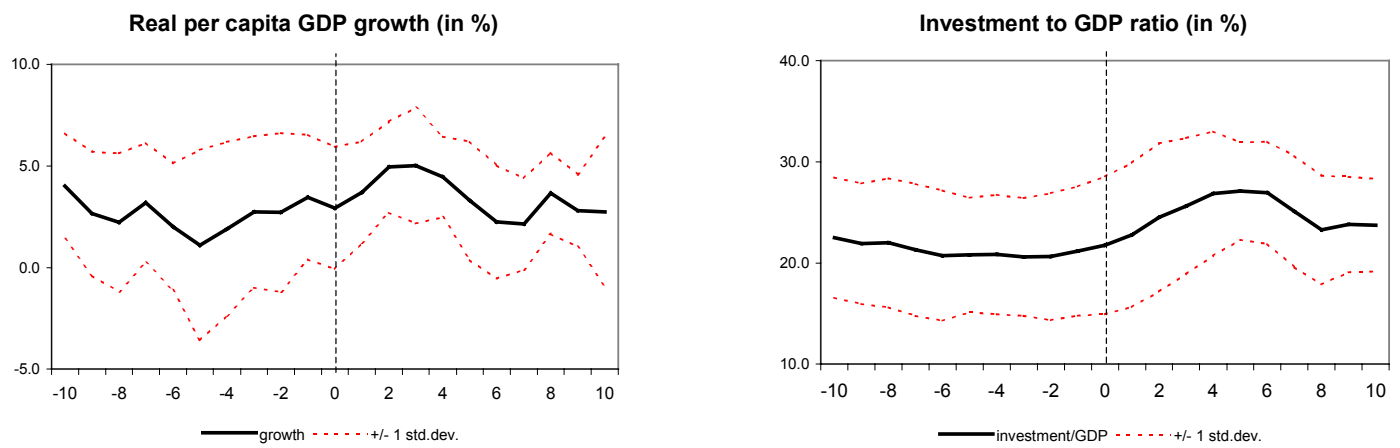

FDI inflows to GDP ratio (in \%)

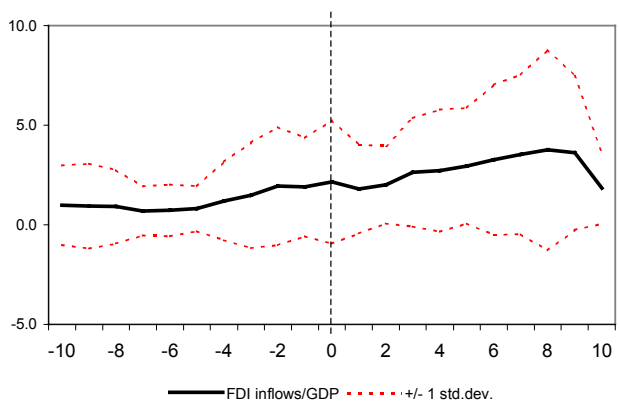

Short-term debt to GDP ratio (in \%)

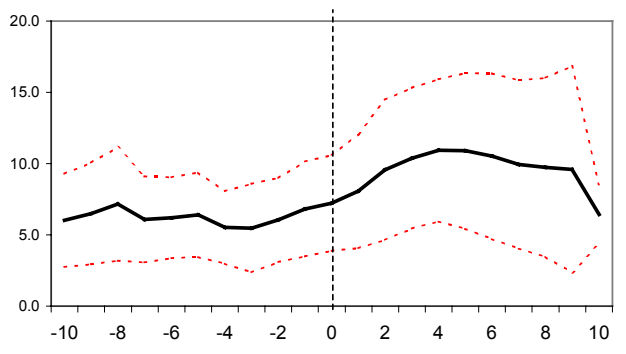

Domestic financial sector liberaliation (in \%)
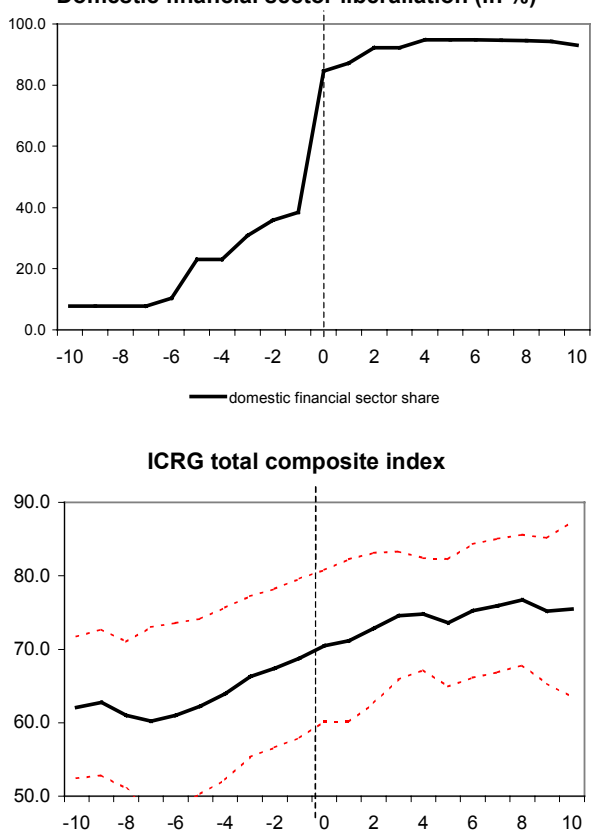

—ICRG total composite index $\ldots . . .++/$ - 1 std.dev

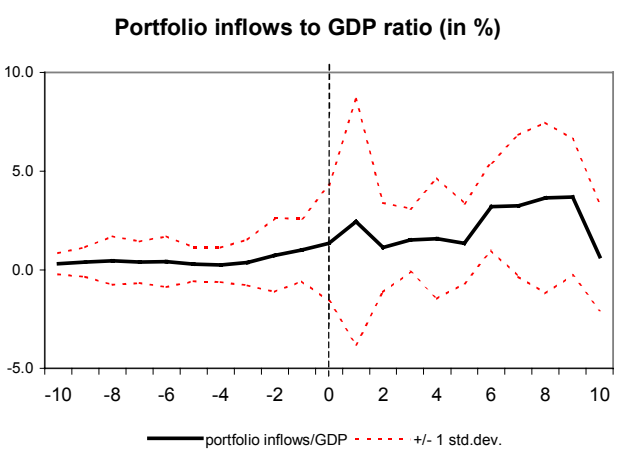

Trade openness to GDP ratio (in \%)

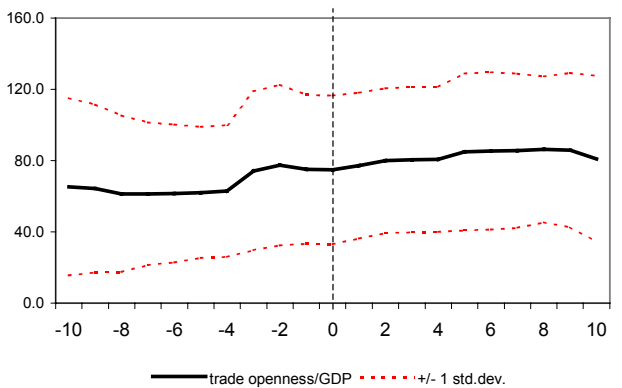

Domestic equity market liberalization (in \%)

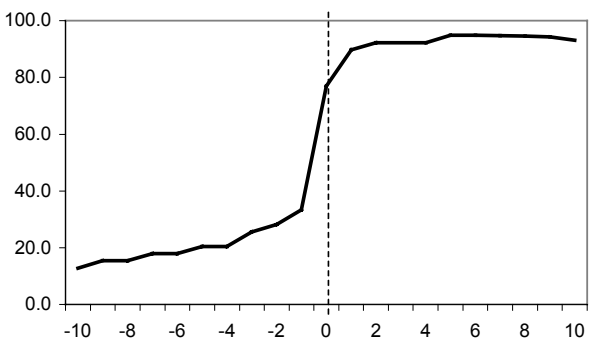

-domestic equity market share

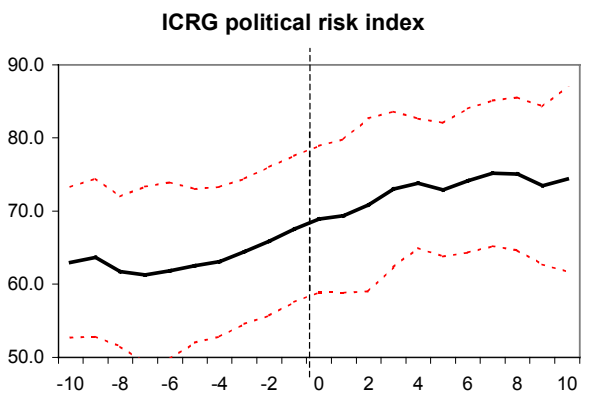

—ICRG political risk index . . . . . + +/- 1 std.dev. 


\subsection{Openness and growth: is there a relationship?}

As a first step of the econometric analysis, this section repeats the analysis typically done in the literature by testing whether open economies per se grow faster than closed ones. The benchmark model is therefore

$$
y_{i, t}=\alpha+\beta D_{i, t}^{L I B}+\gamma X_{i, t}+\varepsilon_{i, t}
$$

with $\mathrm{y}$ as the growth rate, $\mathrm{D}^{\mathrm{LIB}}$ the dummy for capital account openness, and $\mathrm{X}$ as a vector of macroeconomic and institutional controls. The control variables $\mathrm{X}$ include not only those suggested by the standard Barro - Sala-i-Martin growth framework, but also additional variables of interest, which are then added one by one to the model. The above-described Arellano-Bond dynamic panel data estimator is employed.

In addition, distinguishing explicitly between short-run liberalisation $\left(\mathrm{D}^{\text {ST-LIB }}\right)-$ the immediate five years after liberalisation - and the long-run liberalisation period $\left(\mathrm{D}^{\mathrm{LT}-\mathrm{LB}}\right)$ more than five years after liberalisation of the financial account - yields the following model

$$
y_{i, t}=\alpha+\beta_{s t} D_{i, t}^{S T-L I B}+\beta_{l t} D_{i, t}^{L T-L I B}+\gamma X_{i, t}+\varepsilon_{i, t}
$$

Table 1 shows the empirical results for the 45 countries and the period 1980-2002. Consistent with much of the literature, no significant relationship between openness and growth is found (model (1)). However, there is a strong positive and significant link between openness and growth when controlling for financial crises (model (2)). Financial crises are defined as large currency devaluations, following the methodology used in Bussiere and Fratzscher (2002). In other words, financial openness is conducive to growth if one controls for crises. ${ }^{10}$

This finding is in line with those by Eichengreen and Leblang (2003). However, the problem with interpreting these results is that the occurrence of financial crises can not be assumed to be exogenous to financial liberalisation. Leblang (2001) and Bordo, Eichengreen, Klingenbiel and Martinez Peria (2001) show that financial crises are more frequent among closed economies. However, the results found here as well as in Eichengreen and Leblang (2003) imply that financial crises tend to be more severe in open economies in terms of lost growth.

\footnotetext{
${ }^{10}$ The coefficients on the control variables are correctly signed and significant at the $5 \%$ level. A higher initial income per head implies a lower growth rate (catching up effect), higher investment is (as expected) associated with higher growth, the positive sign of government expenditure suggests the presence of a Keynesian effect in the short-run while the political risk indicator (for which an increase represents an improvement) has a positive effect on growth.
} 
Table 1: Effects of liberalisation on growth: Benchmark results

\begin{tabular}{|c|c|c|c|c|c|c|c|c|}
\hline \multirow{2}{*}{$\begin{array}{l}\text { Arellano-Bond dynamic } \\
\text { panel data estimator } \\
\text { Independent variable } \mathrm{X} \text { : }\end{array}$} & \multicolumn{2}{|c|}{ (1) } & \multicolumn{2}{|c|}{ (2) } & \multicolumn{2}{|c|}{ (3) } & \multicolumn{2}{|c|}{ (4) } \\
\hline & coef. & t-stats & coef. & $t$-stats & coef. & t-stats & coef. & t-stats \\
\hline \multicolumn{9}{|l|}{ Openness: } \\
\hline Post-liberalisation & 0.755 & 1.140 & $1.611^{* *}$ & 2.630 & & & & \\
\hline Short-term post-liberalisation & & & & & $1.561 *$ & 1.850 & 2.201 * & * 2.980 \\
\hline Long-term post-liberalisation & & & & & 0.332 & 0.320 & 0.805 & 0.900 \\
\hline \multicolumn{9}{|l|}{ Macroeconomic \& other variables: } \\
\hline Initial income per capita & -0.026 ** & -3.480 & -0.023 ** & -3.500 & $-0.023 * *$ & -2.380 & -0.019 * & * -2.350 \\
\hline Investment $^{1}$ & 0.095 & 1.530 & 0.149 ** & 2.620 & 0.026 & 0.340 & 0.065 & 0.980 \\
\hline Government expenditure $^{1}$ & 0.322 ** & 4.880 & 0.272 ** & 4.540 & 0.266 ** & 2.910 & 0.257 * & * 3.310 \\
\hline Composite political risk indicator & $0.055 *$ & 1.680 & $0.077^{* *}$ & 2.600 & 0.073 & 1.590 & $0.125 *$ & * 3.090 \\
\hline Financial crisis dummy & & & -7.510 ** & -4.920 & & & -9.547 * & * -4.500 \\
\hline test of difference ${ }^{2}$ & & & & & 0.125 & & 0.041 & \\
\hline
\end{tabular}

Distinguishing between the effects of financial liberalisation on short-term versus long-term growth, as in equation (5), reveals that economies tend to grow significantly faster in the immediate five years after liberalisation - both with and without controlling for crises (models (3) and (4)). By contrast, growth after the initial five-year period is not significantly different compared to other periods.

Table 2 shows the extension of the model presented in equation (4) by adding various de facto openness measures, other macroeconomic variables and various institutional factors. Note that each of the variables is added separately to the benchmark model. ${ }^{11}$ Consistent with much of the literature, no significant link is found to exist between the de facto openness measures and growth. For the macroeconomic variables, only short-term debt is significantly negatively related to growth. By contrast, several of the institutional variables are significantly linked to the growth performance of countries. In particular, an improvement in political institutions leads to higher growth.

In summary, the findings presented in the subsection are important ones because they underline that in order to understand the link between financial openness and growth, researchers need to look not only at country-specific characteristics relevant for growth, but also at the time dynamics of the liberalisation process.

\footnotetext{
${ }^{11}$ The coefficients of the other variables are not reported for space reasons and are available upon request.
} 
Table 2: Effects of liberalisation on growth: Additional macroeconomic and institutional variables

\begin{tabular}{|c|c|c|c|c|}
\hline \multirow{2}{*}{$\begin{array}{l}\text { Arellano-Bond dynamic } \\
\text { panel data estimator } \\
\text { Independent variable } \mathrm{X} \text { : }\end{array}$} & \multicolumn{2}{|c|}{$\begin{array}{c}\text { (1) } \\
\text { without crisis control }\end{array}$} & \multicolumn{2}{|c|}{$\begin{array}{c}(2) \\
\text { with crisis control }\end{array}$} \\
\hline & $\gamma$ & $t$-stats & $\gamma$ & \\
\hline \multicolumn{5}{|l|}{ De facto openness measures: } \\
\hline Combined FDI \& portfolio inflows ${ }^{1}$ & 0.006 & 0.220 & 0.010 & 0.430 \\
\hline Combined FDI \& portfolio net flows ${ }^{1}$ & 0.012 & 0.140 & 0.048 & 0.620 \\
\hline Combined FDI \& portfolio in-stocks ${ }^{1}$ & -0.006 & -0.810 & -0.007 & -1.070 \\
\hline Combined FDI \& portfolio net-stocks ${ }^{1}$ & -0.010 & -0.690 & -0.013 & -1.060 \\
\hline \multicolumn{5}{|l|}{ Size and composition of capital inflows: } \\
\hline FDI inflows ${ }^{1}$ & -0.020 & -0.190 & 0.004 & 0.040 \\
\hline Portfolio investment inflows ${ }^{1}$ & 0.013 & 0.390 & 0.017 & 0.560 \\
\hline Trade openness ${ }^{1}$ & 0.015 & 1.090 & 0.006 & 0.510 \\
\hline \multicolumn{5}{|l|}{ Other macroeconomic variables: } \\
\hline Inflation & 0.003 & 0.230 & -0.003 & -0.260 \\
\hline Private consumption ${ }^{1}$ & -0.013 & -0.240 & -0.028 & -0.590 \\
\hline Private investment ${ }^{1}$ & 0.002 & 0.860 & 0.001 & 1.180 \\
\hline Current account $^{1}$ & 0.026 & 0.400 & -0.008 & -0.010 \\
\hline Trade balance $^{1}$ & 0.011 & 0.190 & -0.013 & -0.240 \\
\hline Total debt ${ }^{1}$ & -0.020 & -1.080 & -0.190 & -1.130 \\
\hline Short-term debt ${ }^{1}$ & -0.163 ** & -2.290 & $-0.146 * *$ & -2.370 \\
\hline \multicolumn{5}{|l|}{ Institutional variables: } \\
\hline Total composite risk indicator & $0.186^{* *}$ & 2.850 & 0.139 ** & 3.880 \\
\hline Composite political risk indicator & 0.055 * & 1.680 & $0.077^{* *}$ & 2.600 \\
\hline Quality of Bureaucracy & $-0.839 *$ & -1.850 & $-0.663 *$ & -1.640 \\
\hline Corruption & -0.392 & -1.500 & -0.204 & -0.860 \\
\hline Democratic accountability & 0.131 & 0.530 & 0.095 & 0.430 \\
\hline Government stability & -0.085 & -0.570 & -0.134 & -1.020 \\
\hline Law \& order & -0.233 & -0.960 & -0.277 & -1.050 \\
\hline Socioeconomic conditions & $0.354 * *$ & 2.610 & 0.225 & 1.530 \\
\hline
\end{tabular}

\subsection{Which countries benefit from liberalisation?}

So far the paper has established a positive relationship between growth and openness immediately after liberalisation takes place. Before proceeding to the analysis of the intertemporal trade-off in section 3.4, the present sub-section investigates in detail whether there are certain macroeconomic or institutional characteristics that are a pre-condition for countries to benefit from capital account liberalisation. For that purpose, the estimated model becomes 


$$
y_{i, t}=\alpha+\beta D_{i, t}^{L I B}+\gamma X_{i, t}+\lambda\left(D_{i, t}^{L I B} X_{i, t}\right)+\varepsilon_{i, t}
$$

where openness is now interacted with the macroeconomic or institutional variable $\mathrm{X}_{\mathrm{i}, \mathrm{t}}$. The first column in Table 3 shows the effect $\gamma$ of the variables when a country is closed, and the second column the effect $(\gamma+\lambda)$ when a country is open. The third column indicates whether the difference between both effects is significant, i.e. whether a particular factor has a statistically stronger effect on growth when a country is open as opposed to when it is closed.

Table 3: Interaction of openness and macroeconomic variables

\begin{tabular}{|c|c|c|c|c|c|}
\hline \multirow{2}{*}{$\begin{array}{l}\text { Arellano-Bond dynamic } \\
\text { panel data estimator } \\
\text { Independent variable } \mathrm{X} \text { : }\end{array}$} & \multicolumn{2}{|c|}{$\begin{array}{c}\text { pre- } \\
\text { liberalisation }\end{array}$} & \multicolumn{2}{|c|}{$\begin{array}{c}\text { post } \\
\text { liberalisation }\end{array}$} & \multirow{2}{*}{$\begin{array}{c}\text { test of difference } \\
\text { pre versus post } \\
\text { p-value }\end{array}$} \\
\hline & $\gamma$ & $t$-stats & $(\gamma+\lambda)$ & $p$-value ${ }^{2}$ & \\
\hline \multicolumn{6}{|c|}{ De facto openness measure $\&$ composition of capital inflows: } \\
\hline Combined FDI \& portfolio inflows ${ }^{1}$ & 0.148 & 0.318 & -0.002 & 0.945 & 0.319 \\
\hline FDI inflows $^{1}$ & 0.161 & 0.830 & -0.070 & 0.531 & 0.244 \\
\hline Portfolio investment inflows ${ }^{1}$ & 0.137 & 0.642 & 0.009 & 0.794 & 0.663 \\
\hline Trade openness $^{1}$ & 0.000 & 0.480 & -0.001 & 0.889 & 0.894 \\
\hline \multicolumn{6}{|c|}{ Other macroeconomic \& institutional variables: } \\
\hline Initial income per capita & $-0.032 * *$ & -2.550 & $-0.027 * *$ & 0.001 & 0.726 \\
\hline Investment $^{1}$ & $0.152 * *$ & 2.220 & 0.010 & 0.899 & $0.081^{+}$ \\
\hline Government expenditure $^{1}$ & 0.335 ** & 3.650 & 0.312 ** & 0.000 & 0.838 \\
\hline Composite political risk indicator & 0.033 & 0.388 & $0.093 * *$ & 0.049 & $0.065^{+}$ \\
\hline Financial crisis dummy & -6.156 ** & -2.450 & $-8.173^{* *}$ & 0.000 & $0.093^{+}$ \\
\hline Current account $^{1}$ & 0.058 & 0.710 & -0.007 & 0.931 & 0.512 \\
\hline Trade balance ${ }^{1}$ & 0.075 & 1.060 & -0.051 & 0.454 & $0.090^{+}$ \\
\hline Private consumption ${ }^{1}$ & -0.031 & -0.480 & -0.002 & 0.973 & 0.661 \\
\hline Total debt $^{1}$ & 0.014 & 0.620 & $-0.064 * *$ & 0.008 & $0.004^{++}$ \\
\hline Short-term debt ${ }^{1}$ & 0.097 & 0.800 & $-0.291 * *$ & 0.001 & $0.010^{++}$ \\
\hline \multicolumn{6}{|c|}{$\begin{array}{l}\text { Notes: } \\
1 \text { variable is measured as a ratio relative to GDP. } \\
\text { p-value of test of null hypothesis that the total effect of the respective variable is zero in the liberalisation period. } \\
{ }^{3} \text {-value of test of null hypothesis that the effect of the respective variable is the same in liberalisation as compared } \\
\text { to non-liberalisation period. } \\
{ }^{* *},{ }^{*} \text { and }{ }^{++},{ }^{+} \text {indicate significance at the } 5 \% \text { and } 10 \% \text { levels, respectively. }\end{array}$} \\
\hline
\end{tabular}

The results confirm in particular that financial crises are more severe in terms of a loss in growth when economies are open financially. An open economy suffering a financial crisis grows, on average, $8 \%$ less over the corresponding five-year period compared to non-crisis countries. By contrast, the loss in growth is only $6 \%$ for countries that are closed and experienced a crisis.

Moreover, a further interesting finding is that the quality of institutions seems to be significantly more important for open economies than for closed ones in order to raise the rate 
of economic growth. Not only is there a significant gain in terms of higher growth from improving political institutions in an open economy, but this gain is also significantly larger than that for closed economies.

As to the macroeconomic variables, it is found that the total debt and short-term debt ratios hurt growth only in open economies, confirming the importance of the external debt variables already indicated in Table 2.

\subsection{The intertemporal trade-off: Short-run gain versus long-run pain?}

The present subsection now turns to the question of why there is an intertemporal trade-off between openness and growth. Table 1 showed that economies tend to grow significantly faster in the initial period after liberalisation, while they seem to not gain in the medium- to long-term. Why is this the case? In particular, do some variables spur growth in the short-run, but inhibit growth in the long-run?

To address these questions, the following model is estimated:

$y_{i, t}=\alpha+\beta_{s t} D_{i, t}^{S T-L I B}+\beta_{l t} D_{i, t}^{L T-L I B}+\gamma X_{i, t}+\lambda_{s t}\left(D_{i, t}^{S T-L I B} X_{i, t}\right)+\lambda_{l t}\left(D_{i, t}^{L T-L I B} X_{i, t}\right)+\varepsilon_{i, t}$

which is based on the same idea as equation (6), but distinguishes between the short-run liberalisation period $\left(\mathrm{D}^{\mathrm{ST}-\mathrm{LIB}}\right)$ and the medium- to long-term liberalisation periods $\left(\mathrm{D}^{\mathrm{LT}-\mathrm{LIB}}\right)$.

Tables 4 and 5 show the empirical findings. As to the macroeconomic control variables, a first important result is that poorer economies - proxied by the initial income per capita - gain more from financial liberalisation than richer ones in the immediate aftermath of liberalisation, but not afterwards. Second, investment is positively related to growth only in the years immediately after liberalisation, but not significantly related to growth in the medium- to long-term.

A third important finding is related to the de facto openness measures. Portfolio investment inflows are found to raise growth substantially in the short-run, but not in the long-run. By contrast, countries tend to benefit from FDI inflows only in the medium-to long-run but not in the short-run after liberalisation. The effect of portfolio investment on growth is much stronger than the effect of FDI, which is shown by the size and significance of the coefficient of combined portfolio and FDI inflows in the short-term post liberalisation period. 
Table 4: Intertemporal trade-off of liberalisation: Macroeconomic variables, openness and the composition of capital flows

\begin{tabular}{|c|c|c|c|c|c|c|c|}
\hline \multirow{2}{*}{$\begin{array}{l}\text { Arellano-Bond dynamic } \\
\text { panel data estimator }\end{array}$} & \multicolumn{2}{|c|}{$\begin{array}{c}\text { pre- } \\
\text { liberalisation }\end{array}$} & \multicolumn{2}{|c|}{$\begin{array}{l}\text { short-term } \\
\text { post- } \\
\text { liberalisation }\end{array}$} & \multicolumn{2}{|c|}{$\begin{array}{l}\text { medium/long-term } \\
\text { post- } \\
\text { liberalisation }\end{array}$} & \multirow{2}{*}{$\begin{array}{l}\text { test of difference }{ }^{3} \\
\text { short- vs. long-term } \\
\text { p-value }\end{array}$} \\
\hline & $\gamma$ & $t$-stats & $\left(\gamma+\lambda_{\mathrm{st}}\right)$ & $p$-value ${ }^{2}$ & $\left(\gamma+\lambda_{\mathrm{lt}}\right)$ & $p$-value ${ }^{2}$ & \\
\hline \multicolumn{8}{|c|}{ De facto openness measure \& composition of capital inflows: } \\
\hline Combined FDI \& portfolio inflows ${ }^{1}$ & 0.062 & 0.370 & $0.320 * *$ & 0.049 & 0.056 & 0.597 & $0.091^{+}$ \\
\hline FDI inflows ${ }^{1}$ & 0.074 & 0.360 & 0.129 & 0.566 & 0.319 * & 0.065 & $0.098^{+}$ \\
\hline Portfolio investment inflows ${ }^{1}$ & -0.080 & -0.230 & $0.468 * *$ & 0.031 & -0.014 & 0.673 & $0.030^{++}$ \\
\hline Trade openness $^{1}$ & 0.018 * & 1.730 & 0.022 & 0.253 & 0.026 & 0.213 & 0.875 \\
\hline \multicolumn{8}{|c|}{ Other macroeconomic \& institutional variables: } \\
\hline Initial income per capita & $-0.037 * *$ & -3.170 & $-0.047^{* *}$ & 0.000 & $-0.026 * *$ & 0.001 & $0.004^{++}$ \\
\hline Investment $^{1}$ & 0.096 & 1.280 & 0.125 * & 0.098 & -0.089 & 0.362 & $0.039^{++}$ \\
\hline Government expenditure $^{1}$ & 0.353 ** & 3.680 & $0.318^{* *}$ & 0.000 & 0.219 ** & 0.002 & 0.505 \\
\hline Composite political risk indicator & 0.067 ** & 2.020 & 0.097 & 0.166 & $0.175^{* *}$ & 0.005 & $0.100^{+}$ \\
\hline Financial crisis dummy & $-6.950^{* *}$ & -3.120 & $-12.513 * *$ & 0.023 & $-18.466 * *$ & 0.000 & 0.128 \\
\hline Current account $^{1}$ & 0.084 & 0.980 & -0.023 & 0.852 & 0.017 & 0.845 & 0.699 \\
\hline Trade balance $^{1}$ & 0.077 & 1.060 & -0.027 & 0.793 & -0.017 & 0.815 & 0.901 \\
\hline Private consumption $^{1}$ & -0.023 & -0.340 & -0.017 & 0.842 & -0.019 & 0.774 & 0.974 \\
\hline Total debt ${ }^{1}$ & 0.017 & 0.700 & -0.032 & 0.351 & $-0.064 * *$ & 0.015 & 0.288 \\
\hline Short-term debt ${ }^{1}$ & 0.070 & 0.570 & $-0.420 * *$ & 0.001 & $-0.245^{* *}$ & 0.002 & $0.073^{+}$ \\
\hline \multicolumn{8}{|c|}{$\begin{array}{l}\text { variable is measured as a ratio relative to GDP. } \\
2 \mathrm{p} \text {-value of test of null hypothesis that the total effect of the respective variable is zero in short-term liberalisation period } \\
\text { and long-term liberalisation period, respectively. } \\
\text { p-value of test of null hypothesis that the total effect of the respective variable in short-term liberalisation period }\end{array}$} \\
\hline
\end{tabular}

Table 5: Intertemporal trade-off of liberalisation: ICRG - quality of institutions

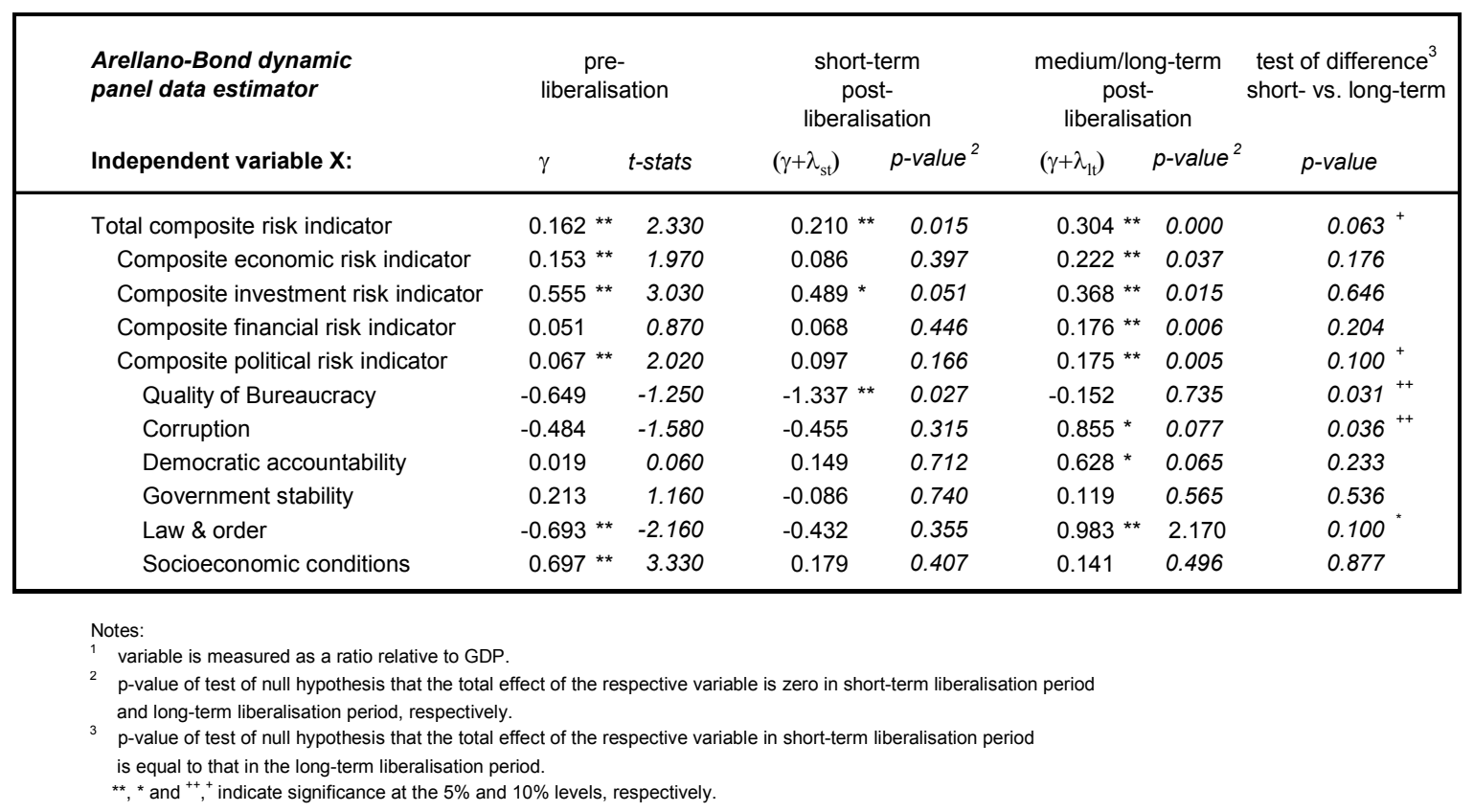


Taking the second and third findings together provides substantial support for the McKinnonPill argument of the "overborrowing" syndrome inherent in the liberalisation process. The results suggest that there is indeed a strong intertemporal trade-off from liberalisation in that a boom in investment and portfolio inflows raises growth immediately after liberalisation, but provides no benefit in the medium to long-run. In fact, the coefficients for both variables are negative, though not statistically significant, in the long-run. This indeed suggests the presence of a boom-bust cycle due to liberalisation, as implied by the theoretical models by McKinnon and Pill $(1997,1999)$.

Fourth, what makes countries benefit from financial liberalisation in the long-run are not only FDI inflows, but in particular also the quality of domestic political institutions. A key finding of the analysis is not only that good institutions raise growth more in open economies in the long-run than in closed ones, but that in the initial period after liberalisation the quality of institutions plays less of a role. One interpretation of this finding is that countries benefited from liberalisation in the short-run post-liberalisation period irrespective of the quality of their political institutions. This is again very much in line with the McKinnon-Pill hypothesis, in which moral hazard and pure domestic institutions lead to a boom in the short-run.

\subsection{Sensitivity analysis}

As the final step of the analysis, several sensitivity and robustness tests of the results are conducted. We focus in particular on three issues: the definition and different types of financial openness, differences across countries and regions, and the role of financial crises.

Turning to the first of these issues - the definition of openness - sections 3.1 to 3.4 have looked also at various de facto openness measures, such as capital inflows and capital stocks, and the composition of capital inflows. The analysis showed some interesting evidence for the importance of the composition of capital inflows. However, another angle to look at the issue is to analyse different types of financial openness. Kaminsky and Schmukler (2003) investigate whether the sequencing of financial liberalisation plays a role in explaining the amplitude of equity market cycles. They ask whether this amplitude is larger if countries first liberalised their capital account, their domestic financial sector, or their domestic equity market. They find that liberalising first the capital account is harmful in that equity market crashes are larger compared to countries where equity or domestic financial markets are liberalised first. 
We conduct a similar analysis for the openness-growth nexus by using the KaminskySchmukler data on the openness of domestic financial sectors and equity markets, and again complement their dataset with EBRD information for acceding countries. We estimate the following model

$$
y_{i, t}=\alpha+\beta_{1} D_{i, t}^{C A}+\beta_{2} D_{i, t}^{D F}+\beta_{3} D_{i, t}^{E Q}+\gamma X_{i, t}+\varepsilon_{i, t}
$$

which is basically the same model as equation (4), but now we distinguish between the dummies of openness of the capital account $\left(D^{C A}\right)$, the domestic financial sector $\left(D^{D F}\right)$ and the equity market $\left(D^{E Q}\right)$ for each country $i$.

Table 6: Sensitivity analysis: The role of sequencing

\begin{tabular}{|c|c|c|c|c|}
\hline \multirow{2}{*}{$\begin{array}{l}\text { Arellano-Bond dynamic } \\
\text { panel data estimator } \\
\text { Independent variable } \mathrm{X} \text { : }\end{array}$} & \multicolumn{2}{|c|}{$\begin{array}{c}\quad(1) \\
\text { without crisis control }\end{array}$} & \multicolumn{2}{|c|}{$\begin{array}{c}\text { (2) } \\
\text { with crisis control }\end{array}$} \\
\hline & $\beta_{\mathrm{z}}$ & $t$-stats & $\beta_{\mathrm{z}}$ & tats \\
\hline \multicolumn{5}{|l|}{ ALL COUNTRIES: } \\
\hline \multicolumn{5}{|l|}{ Post-liberalisation: } \\
\hline Capital account liberalisation $\left(\mathrm{D}^{\mathrm{CA}}\right)$ & -0.403 & -0.43 & 0.198 & 0.24 \\
\hline Domestic financial market liberalisation $\left(\mathrm{D}^{\mathrm{DF}}\right)$ & 1.508 * & 1.81 & 1.512 ** & 2.02 \\
\hline Equity market liberalisation $\left(\mathrm{D}^{\mathrm{EQ}}\right)$ & 0.959 & 0.99 & 1.162 & 1.34 \\
\hline \multicolumn{5}{|l|}{ Tests (p-value): } \\
\hline$H_{0}: \quad D^{C A}=D^{D F}$ & 0.173 & & 0.298 & \\
\hline$H_{0}: D^{C A}=D^{E Q}$ & 0.405 & & 0.512 & \\
\hline$H_{0}: \quad D^{D F}=D^{E Q}$ & 0.710 & & 0.791 & \\
\hline \multicolumn{5}{|l|}{ EMERGING MARKETS ONLY: } \\
\hline \multicolumn{5}{|l|}{ Post-liberalisation: } \\
\hline Capital account liberalisation $\left(\mathrm{D}^{\mathrm{CA}}\right)$ & -0.827 & -0.58 & -0.459 & -0.37 \\
\hline Domestic financial market liberalisation $\left(\mathrm{D}^{\mathrm{DF}}\right)$ & $2.448^{* *}$ & 2.19 & 2.649 ** & 2.75 \\
\hline Equity market liberalisation $\left(\mathrm{D}^{\mathrm{EQ}}\right)$ & 1.033 & 0.71 & 1.342 & 1.08 \\
\hline \multicolumn{5}{|l|}{ Tests (p-value): } \\
\hline$H_{0}: \quad D^{C A}=D^{D F}$ & 0.110 & & 0.078 * & \\
\hline$H_{0}: \quad D^{C A}=D^{E Q}$ & 0.478 & & 0.424 & \\
\hline$H_{0}: \quad D^{D F}=D^{E Q}$ & 0.489 & & 0.458 & \\
\hline
\end{tabular}

Table 6 shows the results for two sets of countries: first, all countries, and second, only emerging market economies. We also compare the result with versus without controlling for financial crises (models (1) and (2)). The key result is that there are large differences between countries depending on the sequencing of the liberalisation process. Countries that liberalise 
their domestic financial sectors first experience significantly higher growth after liberalisation. Countries that liberalise their domestic equity markets first also tend to benefit, though the effect is not statistically significant.

By contrast, countries that first liberalise their capital accounts fare worse: growth in these countries is mostly lower after opening up compared to those that first liberalise domestic financial or equity markets, though this difference is not always statistically significant. Finally, the findings are robust when controlling for financial crises in the model (see model (2) of Table 6).

The second robustness check conducted is to test for regional and country group differences. For this purpose, two models are formulated, analogously to those of equations (4) and (5) above, only that now we are distinguishing between the effects of liberalisation on growth between industrialised countries $\left(\mathrm{D}^{\mathrm{IND}}\right)$, economies in Non-Japan Asia $\left(\mathrm{D}^{\mathrm{AS}}\right)$, Latin American countries $\left(\mathrm{D}^{\mathrm{LA}}\right)$, and acceding countries $\left(\mathrm{D}^{\mathrm{AC}}\right)$ :

$$
y_{i, t}=\alpha+\sum_{z}\left(\beta^{z} D_{i}^{z}\right) D_{i, t}^{L I B}+\gamma X_{i, t}+\varepsilon_{i, t} \quad z=I N D, A S, L A, A C
$$

to analyse the trade-off between being financially open and financially closed, and

$$
\begin{aligned}
y_{i, t}= & \alpha+\sum_{z}\left(\beta_{s t}^{z} D_{i}^{z}\right) D_{i, t}^{S T-L I B} \\
& +\sum_{z}\left(\beta_{l t}^{z} D_{i}^{z}\right) D_{i, t}^{L T-L I B}+\gamma X_{i, t}+\varepsilon_{i, t} \quad z=I N D, A S, L A, A C
\end{aligned}
$$

to investigate the intertemporal trade-off between short-run and long-run liberalisation effects.

Table 7 shows the results for the estimations of equation (9) in the upper panel and of equation (10) in the lower panel. Overall we find evidence for the presence of significant differences across regional/country groupings. When regressions control for the presence of a crisis, the countries that benefit from liberalisation per se are the industrialised, the Latin American and the acceding countries. When the model does not control for the presence of a crisis, the only effect that is still statistically significant is the one for acceding countries.

Looking at the short-term versus long-term trade-off, all emerging market regions experienced a short-term acceleration in growth, though the effect is statistically significant only for Latin America and the acceding countries when controlling for crises, and only for 
the acceding countries when not controlling for such events. By contrast, in the long-run, economies in Latin America and Asia experience lower growth, whereas acceding countries continue to grow significantly faster.

Table 7: Sensitivity analysis: Regional differences

\begin{tabular}{|c|c|c|c|c|}
\hline \multirow{2}{*}{$\begin{array}{l}\text { Arellano-Bond dynamic } \\
\text { panel data estimator } \\
\text { Independent variable X: }\end{array}$} & \multicolumn{2}{|c|}{$\begin{array}{l}\text { (1) } \\
\text { without crisis control }\end{array}$} & \multicolumn{2}{|c|}{$\begin{array}{c}(2) \\
\text { with crisis control }\end{array}$} \\
\hline & $\beta_{\mathrm{z}}$ & $t$-stats & $\beta_{\mathrm{z}}$ & $t$-stats \\
\hline \multicolumn{5}{|l|}{ Openness: } \\
\hline \multicolumn{5}{|l|}{ Post-liberalisation: } \\
\hline Industrialised countries & 0.894 & 1.50 & 1.149 ** & 2.16 \\
\hline Asian economies & -0.433 & -0.38 & 0.928 & 0.88 \\
\hline Latin American economies & 1.022 & 0.95 & 1.942 ** & 1.98 \\
\hline Acceding countries & $1.426^{* *}$ & 3.24 & 1.435 ** & 3.65 \\
\hline \multicolumn{5}{|l|}{ Short-term post-liberalisation } \\
\hline Industrialised countries & -0.618 & -0.63 & 0.118 & 0.13 \\
\hline Asian economies & 0.674 & 1.02 & 1.086 & 1.15 \\
\hline Latin American economies & 0.685 & 1.20 & 1.530 * & 1.63 \\
\hline Acceding countries & $1.200^{* *}$ & 3.08 & 1.232 ** & 3.45 \\
\hline \multicolumn{5}{|l|}{ Long-term post-liberalisation } \\
\hline Industrialised countries & 0.580 & 0.53 & 1.214 & 1.21 \\
\hline Asian economies & $-2.282 * *$ & -2.17 & -1.167 & -1.19 \\
\hline Latin American economies & $-1.670 *$ & -1.63 & -0.747 & -0.79 \\
\hline Acceding countries & $1.041^{* *}$ & 2.36 & $0.947^{* *}$ & 2.34 \\
\hline \multicolumn{5}{|l|}{ Notes: } \\
\hline \multicolumn{5}{|c|}{ variable is measured as a ratio relative to GDP. } \\
\hline \multicolumn{5}{|c|}{${ }^{* *},{ }^{*}$ indicate significance at the $5 \%$ and $10 \%$ levels, respectively. } \\
\hline \multicolumn{5}{|c|}{ Countries excluded from analysis in this table only are Russia, South Africa and Turkey } \\
\hline \multicolumn{5}{|c|}{ Results for regressions for "post-liberalisation" are based on equation (9) in the } \\
\hline
\end{tabular}

Overall, what these results suggest is that the acceding countries do not conform to the above presented finding of a "short-run gain, long-run pain" from capital account liberalisation among emerging markets. In fact, for acceding countries liberalisation so far seems to have been an unconditional gain in terms of higher growth. By contrast, Asian economies seem to have benefited the least from the liberalisation process. Although growth was significantly higher in the immediate aftermath of liberalisation, subsequent growth was lower, which from a comparison in Table 7 seems to be mostly explained the severity of the regional financial crisis in the second half of the 1990s.

Moreover, an important qualifier of this result is that Asian economies tended to grow relatively quickly in the 1980s before financial liberalisation, whereas Latin American and 
Eastern European economies grew little, or experienced even economic contractions in the years prior to opening up. Since the estimates given in the first panel of Table 7 show the differences in growth of being open relative to being closed, the absolute level of growth may still have been higher for Asian economies under liberalisation than for e.g. Latin American countries.

One important finding of the analysis is that acceding countries so far seem to defy the intertemporal trade-off that emerging markets in Asia and Latin America experienced. However, one important caveat is that acceding countries have liberalised only relatively recently, i.e. mostly within the last 5 to 10 years, whereas most emerging markets in Asia and Latin America did so already in the 1980s or early 1990s. Hence it is not possible and too early to speak of a "long-run gain" for acceding countries. In particular, few acceding countries have so far suffered financial crises since their transition to market economies. This point is also underlined by the similarity of the estimates for acceding countries when controlling and when not controlling for crises. It therefore remains to be seen over the current and next decades whether acceding countries can continue to unanimously gain from the financial liberalisation process by achieving higher economic growth.

\section{Conclusions}

The objective of the paper has been to analyse the financial liberalisation-growth nexus from a new perspective. The paper has investigated whether capital account liberalisation creates an intertemporal trade-off, i.e. whether countries experience a short-run gain at the expense of a medium- to long-run pain due to opening up their capital account. Conceptually such a trade-off can exist for different reasons. Gourinchas and Jeanne (2002) argue that the firstorder gains of financial liberalisation are relatively small compared with the longer-run gains coming from the locking in of domestic reforms. The argument by McKinnon and Pill (1997, 1999) states that such a trade-off may be created by an investment and lending boom immediately after liberalisation, which ultimately may turn into a bust and a collapse, resulting in lower growth and possibly recession and financial crises in the medium-term.

The paper has presented evidence in favour of the existence of such a trade-off from capital account liberalisation for a broad set of 45 emerging economies and industrialised countries. The opening of the capital account led to a $1.5 \%$ higher growth during the first five years after 
liberalisation. Growth subsequently returned to or even below its pre-liberalisation rate for the overall average of the countries.

However, there are significant regional differences in that it has been in particular many Asian and Latin American economies that have gone through such a cycle of faster short-run growth but lower medium-run growth in the 1980s and 1990s, whereas acceding countries so far have unambiguously gained from financial liberalisation. An important caveat is, however, that acceding countries have liberalised much more recently and have mostly not experienced severe financial crises and economic contractions as many other emerging markets did. It therefore remains to be seen whether acceding countries can continue to reap benefits from liberalisation without experiencing any setbacks in terms of economic growth and in terms of their catching-up potential with industrialised countries.

The main implication of the paper is that it is important to understand this intertemporal tradeoff in order to understand why some countries gain from liberalisation whereas others may experience lower and more volatile growth. It sheds light on the possible reason why the literature so far has not found a compelling link between openness and growth. The findings of the paper also suggest that there are strong time-varying relationships between openness, several economic determinants and economic growth. In particular, the paper has presented evidence that economic growth immediately after liberalisation is often driven by an investment boom and a surge in portfolio and debt inflows, which then become detrimental to economic growth in the medium- to long-run. By contrast, the factors that lead to higher growth in the longer term tend to be the quality of domestic institutions, the size of FDI inflows and the sequencing of the liberalisation process. These may be important points for policy-makers' managing of their countries' transition process and integration into the world economy. 


\section{References}

Arellano, Manuel and Stephen Bond (1991). Some Tests of Specification for Panel Data: Monte Carlo Evidence and an Application to Employment Equations, Review of Economic Studies 58: 277-297.

Arteta, Carlos, Barry Eichengreen and Charles Wyplosz (2001). Do the Effects of Capital Account Liberalisation Depend on the Stage of Financial and Institutional Development? unpublished manuscript, University of California, Berkeley.

Bailliu, Jeannine (2000). Private Capital Flows, Financial Development, and Economic Growth in Developing Countries, Bank of Canada Working Paper No. 2000-15.

Barro, Robert (1991). Economic Growth in a Cross-Section of Countries, Quarterly Journal of Economics 106: 407-43.

Barro, Robert and Xavier Sala-i-Martin (1995). Economic Growth, McGraw-Hill, New York.

Beck, Thorsten, Ross Levine, Norman Loayza (2000). Finance and Sources of Growth, Journal of Financial Economics 58: 261-300.

Bekaert, Geert and Campbell R. Harvey (1995). Time-Varying World Market Integration, Journal of Finance 50: 403-444.

Bekaert, Geert, Campbell Harvey and Christian Lundblad (2001). Emerging Equity Markets and Economic Development, Journal of Development Economics 66: 465-504.

Bhagwati, Jagdish (1998). The Capital Myth: The Difference Between Trade in Widgets and Trade in Dollars, Foreign Affairs 77: 7-12.

Bordo, Michael, Barry Eichengreen, Daniela Klingenbiel and Soledad Maria Martinez-Peria (2001). Is the Crisis Problem Growing More Severe? Economic Policy 24: 51-82.

Bussiere, Matthieu and Marcel Fratzscher (2002), Towards a new Early Warning System of financial crises, ECB Working Paper No. 145, May 2002.

Chinn, Menzie and Hiro Ito (2002). Capital Account Liberalisation, Institutions and Financial Development: Cross Country Evidence, NBER Working Paper No. 8967.

Demirguc-Kunt, Asli and Ross Levine (2001). Financial Structure and Economic Growth. MIT Press.

Edison, Hali, Michael Klein, Luca Ricci and Torsten Slok (2002a). Capital Account Liberalisation and Economic Performance: Survey and Synthesis, IMF Working Paper No 120.

Edison, Hali, Ross Levine, Luca Ricci and Torsten Slok (2002b). International Financial Integration and Economic Growth, IMF Working Paper No 145.

Edison, Hali and Francis Warnock (2002). A simple measure of the intensity of capital controls, Journal of Empirical Finance. 
Edwards, Sebastian (1998). Openness, Productivity, and Growth: What Do We Really Know?, Economic Journal 108: 383-398.

Edwards, Sebastian (2001). Capital Flows and Economic Performance: Are Emerging Economies Different? NBER Working Paper no. 8076 (January).

Eichengreen, Barry (2002). Capital Account Liberalisation: What do the Cross-Country Studies Tell Us?, World Bank Economic Review, March.

Eichengreen, Barry and David Leblang (2003). Capital Account Liberalisation and Growth: Was Mr. Mahatir Right? International Journal of Finance and Economics.

Gourinchas, Pierre-Olivier and Olivier Jeanne (2002). On the Benefits of Capital Account Liberalisation for Emerging Economies, unpublished manuscript, Princeton University and IMF.

Grilli, V. and G. M. Milesi-Ferretti (1995). Economic Effects and Structural Determinants of Capital Controls, IMF Staff Papers 42: 517-551.

International Monetary Fund (various years). Annual Report on Exchange Arrangements and Exchange Restrictions, Washington, D.C.: IMF.

Kaminsky, Graciela, and Sergio Schmukler (2003). Short-Run Pain, Long-Run Gain: The Effects of Financial Liberalisation. IMF Working Paper No. 34.

King, R. G., and R. Levine. 1993. Finance, Entrepreneurship and Growth. Journal of Monetary Economics 32: 513-542.

Klein, Michael and Giovanni Olivei (1999). "Capital Account Liberalisation, Financial Depth, and Economic Growth,” NBER Working Paper no. 7384 (October).

Kraay, Aart (1998). In Search of the Macroeconomic Effects of Capital Account Liberalizations, World Bank.

La Porta, R., F. Lopez de Silanes, A. Shleifer, and R. Vishny (1998). Law and finance, Journal of Political Economy 106(6): 1113-1155.

Lane, Philip and Gian Maria Milesi-Ferretti (2001). The External Wealth of Nations:

Measures of Foreign Assets and Liabilities for Industrial and Developing Nations, Journal of International Economics 55: 263-294.

Leblang, David A. (2001). To Devalue or To Defend: The Political Economy of Exchange Rate Policy in the Developing World, unpublished manuscript, University of Colorado, Boulder.

Levine, Ross and Sara Zervos (1998). Stock Markets, Banks, and Economic Growth, American Economic Review 88: 537-58.

Levine, Ross, Norman Loayza and Thorsten Beck (2000) Financial Intermediation and Growth: Causality and Causes, Journal of Monetary Economics 46: 31-77.

McKinnon, Ronald and Huw Pill (1997). Credible Economic Liberalizations and Overborrowing, American Economic Review 87: 189-93. 
McKinnon, Ronald and Huw Pill (1999). Exchange-Rate Regimes for Emerging Markets: Moral Hazard and International Overborrowing, Oxford Review of Economic Policy 15(3): 19-39.

Nickell, Steven (1981). Biases in dynamic models with fixed effects, Econometrica 49: 14171426.

Quinn, Dennis (1997). The Correlates of Changes in International Financial Regulation, American Political Science Review 91: 531-551.

Quinn, D., C. Inclan and A. M. Toyoda (2001). How and Where Capital Account Liberalisation Leads to Growth, Unpublished working paper, Georgetown University.

Rajan, R. G. and L. Zingales (1998). Financial Dependence and Growth, American Economic Review 88: 559-586.

Rodrik, Dani (1998). Who Needs Capital-Account Convertibility? in Peter Kenen (ed), Should the IMF Pursue Capital Account Convertibility? Essays in International Finance no. 207, Princeton: Princeton University Press (May).

Stiglitz, Joseph (2000). Capital Market Liberalisation, Economic Growth and Instability, World Development 25: 1075-1086.

Stiglitz, Joseph (2002). Globalization and its Discontents, New York: W.W. Norton.

Williamson, John and Molly Mahar (1998). A Survey of Financial Liberalisation, Essays in International Finance no. 211, International Finance Section, Department of Economics, Princeton University (November). 


\section{Appendix}

\section{- Country sample:}

Argentina, Brazil, Bulgaria, Canada, Chile, China, Colombia, Cyprus, Czech Republic, Ecuador, Estonia, France, Germany, Greece, Hong Kong, Hungary, India, Indonesia, Ireland, Italy, Japan, Korea, Latvia, Lithuania, Malaysia, Mexico, Pakistan, Peru, Philippines, Poland, Portugal, Romania, Russia, Singapore, Slovakia, Slovenia, South Africa, Spain, Sri Lanka, Taiwan, Thailand, Turkey, UK, US, Venezuela.

\section{- Definition and sources of macroeconomic and institutional variables:}

\begin{tabular}{|c|c|c|}
\hline Variable & Description & Source \\
\hline De jure openness measure: & $\begin{array}{l}\text { IMF AREAR plus judgmental } \\
\text { assessments }\end{array}$ & $\begin{array}{l}\text { Kaminsky and Schmukler } \\
\text { (2003), IMF AREAR, EBRD } \\
\text { Transition Reports }\end{array}$ \\
\hline $\mathrm{D}^{\mathrm{CA}}$ & Capital account liberalisation $0-1$ & IMF AREAR, EBRD \\
\hline $\mathrm{D}^{\mathrm{DF}}$ & $\begin{array}{l}\text { Domestic financial sector } \\
\text { liberalisation }(0-1 \text { dummy) }\end{array}$ & $\begin{array}{l}\text { Kaminsky and Schmukler } \\
\text { (2003), EBRD }\end{array}$ \\
\hline $\mathrm{D}^{\mathrm{EQ}}$ & $\begin{array}{l}\text { Domestic equity market } \\
\text { liberalisation ( } 0-1 \text { dummy) }\end{array}$ & $\begin{array}{l}\text { Kaminsky and Schmukler } \\
\text { (2003), EBRD }\end{array}$ \\
\hline \multicolumn{3}{|l|}{ De facto openness measures: } \\
\hline $\begin{array}{l}\text { Combined FDI \& portfolio } \\
\text { inflows }\end{array}$ & $\begin{array}{l}\text { FDI inflows plus portfolio } \\
\text { inflows, } \% \text { of GDP }\end{array}$ & IMF IFS and WEO \\
\hline $\begin{array}{l}\text { Combined FDI \& portfolio } \\
\text { net flows }\end{array}$ & $\begin{array}{l}\text { Net FDI flows plus net portfolio } \\
\text { flows, } \% \text { of GDP }\end{array}$ & IMF IFS and WEO \\
\hline $\begin{array}{l}\text { Combined FDI \& portfolio } \\
\text { in-stocks }\end{array}$ & $\begin{array}{l}\text { Cumulated FDI inflows plus } \\
\text { portfolio inflows, \% of GDP }\end{array}$ & IMF IFS and WEO \\
\hline $\begin{array}{l}\text { Combined FDI \& portfolio } \\
\text { net-stocks }\end{array}$ & $\begin{array}{l}\text { Cumulated net FDI flows plus } \\
\text { net portfolio flows, } \% \text { of GDP }\end{array}$ & IMF IFS and WEO \\
\hline \multicolumn{3}{|c|}{$\begin{array}{l}\text { Size and composition of } \\
\text { capital inflows: }\end{array}$} \\
\hline FDI inflows & $\%$ of GDP & IMF IFS and WEO \\
\hline Portfolio investment inflows & $\%$ of GDP & IMF IFS and WEO \\
\hline Trade openness & Exports plus imports, $\%$ of GDP & IMF IFS and WEO \\
\hline \multicolumn{3}{|l|}{$\begin{array}{l}\text { Other macroeconomic } \\
\text { variables: }\end{array}$} \\
\hline Inflation & Log difference of CPI or PPI & IMF IFS and WEO \\
\hline Private consumption & $\%$ of GDP & IMF IFS and WEO \\
\hline Private investment & $\%$ of GDP & IMF IFS and WEO \\
\hline Current account & $\%$ of GDP & IMF IFS and WEO \\
\hline Trade balance & $\%$ of GDP & IMF IFS and WEO \\
\hline Total debt & $\%$ of GDP & WEFA World Market Monitor \\
\hline Short-term debt & $\%$ of GDP & WEFA World Market Monitor \\
\hline \multicolumn{3}{|l|}{ Institutional variables: } \\
\hline Total composite risk indicator & $\begin{array}{l}\text { Weighted indicator of political, } \\
\text { economic and financial risk: } 0 \\
\text { worst institutions, } 100 \text { best } \\
\text { institutions }\end{array}$ & $\begin{array}{l}\text { ICRG - International Country } \\
\text { Risk Guide }\end{array}$ \\
\hline $\begin{array}{l}\text { Composite political risk } \\
\text { indicator }\end{array}$ & $\begin{array}{l}\text { Weighted indicator of } 12 \\
\text { individual political risk } \\
\text { components: } 0 \text { worst institutions, } \\
100 \text { best institutions }\end{array}$ & $\begin{array}{l}\text { ICRG - International Country } \\
\text { Risk Guide }\end{array}$ \\
\hline $\begin{array}{l}12 \text { individual components of } \\
\text { composite political risk } \\
\text { indicator }\end{array}$ & $\begin{array}{l}\text { Indicators ranging either from } 0 \\
\text { to } 6 \text { or from } 0 \text { to } 12: 0 \text { worst } \\
\text { institutions, } 6 / 12 \text { best institutions }\end{array}$ & $\begin{array}{l}\text { ICRG - International Country } \\
\text { Risk Guide }\end{array}$ \\
\hline
\end{tabular}




\section{European Central Bank working paper series}

For a complete list of Working Papers published by the ECB, please visit the ECB's website (http://www.ecb.int).

202 "Aggregate loans to the euro area private sector" by A. Calza, M. Manrique and J. Sousa, January 2003.

203 "Myopic loss aversion, disappointment aversion and the equity premium puzzle" by D. Fielding and L. Stracca, January 2003.

204 "Asymmetric dynamics in the correlations of global equity and bond returns" by L. Cappiello, R.F. Engle and K. Sheppard, January 2003.

205 "Real exchange rate in an inter-temporal n-country-model with incomplete markets" by B. Mercereau, January 2003.

206 "Empirical estimates of reaction functions for the euro area" by D. Gerdesmeier and B. Roffia, January 2003.

207 “A comprehensive model on the euro overnight rate” by F. R. Würtz, January 2003.

208 "Do demographic changes affect risk premiums? Evidence from international data" by A. Ang and A. Maddaloni, January 2003.

209 “A framework for collateral risk control determination” by D. Cossin, Z. Huang, D. Aunon-Nerin and F. González, January 2003.

210 "Anticipated Ramsey reforms and the uniform taxation principle: the role of international financial markets" by S. Schmitt-Grohé and M. Uribe, January 2003.

211 “Self-control and savings” by P. Michel and J.P. Vidal, January 2003.

212 "Modelling the implied probability of stock market movements" by E. Glatzer and M. Scheicher, January 2003.

213 “Aggregation and euro area Phillips curves” by S. Fabiani and J. Morgan, February 2003.

214 "On the selection of forecasting models" by A. Inoue and L. Kilian, February 2003.

215 "Budget institutions and fiscal performance in Central and Eastern European countries" by H. Gleich, February 2003.

216 "The admission of accession countries to an enlarged monetary union: a tentative assessment” by M. Ca'Zorzi and R. A. De Santis, February 2003.

217 "The role of product market regulations in the process of structural change" by J. Messina, March 2003. 
218 "The zero-interest-rate bound and the role of the exchange rate for monetary policy in Japan” by G. Coenen and V. Wieland, March 2003.

219 "Extra-euro area manufacturing import prices and exchange rate pass-through" by B. Anderton, March 2003.

220 "The allocation of competencies in an international union: a positive analysis" by M. Ruta, April 2003.

221 "Estimating risk premia in money market rates" by A. Durré, S. Evjen and R. Pilegaard, April 2003.

222 "Inflation dynamics and subjective expectations in the United States" by K. Adam and M. Padula, April 2003.

223 "Optimal monetary policy with imperfect common knowledge" by K. Adam, April 2003.

224 "The rise of the yen vis-à-vis the ("synthetic") euro: is it supported by economic fundamentals?” by C. Osbat, R. Rüffer and B. Schnatz, April 2003.

225 "Productivity and the ("synthetic") euro-dollar exchange rate" by C. Osbat, F. Vijselaar and B. Schnatz, April 2003.

226 "The central banker as a risk manager: quantifying and forecasting inflation risks" by L. Kilian and S. Manganelli, April 2003.

227 “Monetary policy in a low pass-through environment” by T. Monacelli, April 2003.

228 "Monetary policy shocks - a nonfundamental look at the data" by M. Klaeffing, May 2003.

229 “How does the ECB target inflation?” by P. Surico, May 2003.

230 "The euro area financial system: structure, integration and policy initiatives" by P. Hartmann, A. Maddaloni and S. Manganelli, May 2003.

23I "Price stability and monetary policy effectiveness when nominal interest rates are bounded at zero" by G. Coenen, A. Orphanides and V. Wieland, May 2003.

232 "Describing the Fed's conduct with Taylor rules: is interest rate smoothing important?" by E. Castelnuovo, May 2003.

233 "The natural real rate of interest in the euro area" by N. Giammarioli and N. Valla, May 2003.

234 "Unemployment, hysteresis and transition" by M. León-Ledesma and P. McAdam, May 2003.

235 "Volatility of interest rates in the euro area: evidence from high frequency data" by N. Cassola and C. Morana, June 2003. 
236 "Swiss monetary targeting 1974-1996: the role of internal policy analysis" by G. Rich, June 2003.

237 "Growth expectations, capital flows and international risk sharing" by O. Castrén, M. Miller and R. Stiegert, June 2003.

238 "The impact of monetary union on trade prices" by R. Anderton, R. E. Baldwin and D. Taglioni, June 2003.

239 "Temporary shocks and unavoidable transitions to a high-unemployment regime" by W. J. Denhaan, June 2003.

240 "Monetary policy transmission in the euro area: any changes after EMU?" by I. Angeloni and M. Ehrmann, July 2003.

24I Maintaining price stability under free-floating: a fearless way out of the corner?" by C. Detken and V. Gaspar, July 2003.

242 "Public sector efficiency: an international comparison" by A. Afonso, L. Schuknecht and V. Tanzi, July 2003.

243 "Pass-through of external shocks to euro area inflation" by E. Hahn, July 2003.

244 "How does the ECB allot liquidity in its weekly main refinancing operations? A look at the empirical evidence” by S. Ejerskov, C. Martin Moss and L. Stracca, July 2003.

245 "Money and payments: a modern perspective" by C. Holthausen and C. Monnet, July 2003.

246 "Public finances and long-term growth in Europe - evidence from a panel data analysis" by D. R. de Ávila Torrijos and R. Strauch, July 2003.

247 "Forecasting euro area inflation: does aggregating forecasts by HICP component improve forecast accuracy?" by K. Hubrich, August 2003.

248 "Exchange rates and fundamentals" by C. Engel and K. D. West, August 2003.

249 "Trade advantages and specialisation dynamics in acceding countries" by A. Zaghini, August 2003.

250 "Persistence, the transmission mechanism and robust monetary policy" by I. Angeloni, G. Coenen and F. Smets, August 2003.

25 I "Consumption, habit persistence, imperfect information and the lifetime budget constraint" by A. Willman, August 2003.

252 "Interpolation and backdating with a large information set" by E. Angelini, J. Henry and M. Marcellino, August 2003.

253 "Bond market inflation expectations and longer-term trends in broad monetary growth and inflation in industrial countries, 1880-200I" by W. G. Dewald, September 2003. 
254 "Forecasting real GDP: what role for narrow money?" by C. Brand, H.-E. Reimers and F. Seitz, September 2003.

255 "Is the demand for euro area M3 stable?" by A. Bruggeman, P. Donati and A. Warne, September 2003.

256 "Information acquisition and decision making in committees: a survey" by K. Gerling, H. P. Grüner, A. Kiel and E. Schulte, September 2003.

257 “Macroeconomic modelling of monetary policy” by M. Klaeffling, September 2003.

258 "Interest rate reaction functions and the Taylor rule in the euro area" by P. GerlachKristen, September 2003.

259 "Implicit tax co-ordination under repeated policy interactions" by M. Catenaro and J.-P. Vidal, September 2003.

260 "Aggregation-theoretic monetary aggregation over the euro area, when countries are heterogeneous” by W. A. Barnett, September 2003.

261 "Why has broad money demand been more stable in the euro area than in other economies? A literature review” by A. Calza and J. Sousa, September 2003.

262 "Indeterminacy of rational expectations equilibria in sequential financial markets" by P. Donati, September 2003.

263 "Measuring contagion with a Bayesian, time-varying coefficient model" by M. Ciccarelli and A. Rebucci, September 2003.

264 "A monthly monetary model with banking intermediation for the euro area" by A. Bruggeman and M. Donnay, September 2003.

265 "New Keynesian Phillips Curves: a reassessment using euro area data" by P. McAdam and A. Willman, September 2003.

266 "Finance and growth in the EU: new evidence from the liberalisation and harmonisation of the banking industry" by D. Romero de Ávila, September 2003.

267 "Comparing economic dynamics in the EU and CEE accession countries" by R. Süppel, September 2003.

268 "The output composition puzzle: a difference in the monetary transmission mechanism in the euro area and the US" by I. Angeloni, A. K. Kashyap, B. Mojon and D. Terlizzese, September 2003.

269 "Zero lower bound: is it a problem with the euro area?" by G. Coenen, September 2003.

270 "Downward nominal wage rigidity and the long-run Phillips curve: simulation-based evidence for the euro area" by G. Coenen, September 2003.

27I “Indeterminacy and search theory” by N. Giammarioli, September 2003. 
272 "Inflation targets and the liquidity trap" by M. Klaeffling and V. López Pérez, September 2003.

273 "Definition of price stability, range and point inflation targets: the anchoring of long-term inflation expectations" by E. Castelnuovo, S. Nicoletti-Altimari and D. RodriguezPalenzuela, September 2003.

274 "Interpreting implied risk neutral densities: the role of risk premia" by P. Hördahl and D. Vestin, September 2003.

275 "Identifying the monetary transmission mechanism using structural breaks" by A. Beyer and R. Farmer, September 2003.

276 "Short-term estimates of euro area real GDP by means of monthly data" by G. Rünstler and F. Sédillot, September 2003.

277 "On the indeterminacy of determinacy and indeterminacy" by A. Beyer and R. Farmer, September 2003.

278 "Relevant economic issues concerning the optimal rate of inflation" by D. R. Palenzuela, G. Camba-Méndez and J. Á. García, September 2003.

279 "Designing targeting rules for international monetary policy cooperation" by G. Benigno and P. Benigno, October 2003.

280 “Inflation, factor substitution and growth" by R. Klump, October 2003.

28I "Identifying fiscal shocks and policy regimes in OECD countries" by G. de Arcangelis and S. Lamartina, October 2003.

282 "Optimal dynamic risk sharing when enforcement is a decision variable" by T. V. Koeppl, October 2003.

283 "US, Japan and the euro area: comparing business-cycle features" by P. McAdam, November 2003.

284 "The credibility of the monetary policy 'free lunch"' by J. Yetman, November 2003.

285 "Government deficits, wealth effects and the price level in an optimizing model" by B. Annicchiarico, November 2003.

286 "Country and sector-specific spillover effects in the euro area, the United States and Japan" by B. Kaltenhaeuser, November 2003.

287 “Consumer inflation expectations in Poland” by T. Łyziak, November 2003.

288 “Implementing optimal control cointegrated I(I) structural VAR models" by F. V. Monti, November 2003.

289 "Monetary and fiscal interactions in open economies" by G. Lombardo and A. Sutherland, November 2003. 
290 "Inflation persistence and robust monetary policy design" by G. Coenen, November 2003.

291 "Measuring the time-inconsitency of US monetary policy” by P. Surico, November 2003.

292 "Bank mergers, competition and liquidity" by E. Carletti, P. Hartmann and G. Spagnolo, November 2003.

293 “Committees and special interests” by M. Felgenhauer and H. P. Grüner, November 2003.

294 "Does the yield spread predict recessions in the euro area?" by F. Moneta, December 2003.

295 “Optimal allotment policy in the eurosystem's main refinancing operations?" by C. Ewerhart, N. Cassola, S. Ejerskov and N. Valla, December 2003.

296 "Monetary policy analysis in a small open economy using bayesian cointegrated structural VARs?" by M. Villani and A. Warne, December 2003.

297 “Measurement of contagion in banks' equity prices” by R. Gropp and G. Moerman, December 2003.

298 "The lender of last resort: a 2 I st century approach" by X. Freixas, B. M. Parigi and J.-C. Rochet, December 2003.

299 "Import prices and pricing-to-market effects in the euro area" by T. Warmedinger, January 2004.

300 "Developing statistical indicators of the integration of the euro area banking system" by M. Manna, January 2004.

301 "Inflation and relative price asymmetry” by A. Rátfai, January 2004.

302 “Deposit insurance, moral hazard and market monitoring” by R. Gropp and J. Vesala, February 2004.

303 "Fiscal policy events and interest rate swap spreads: evidence from the EU" by A. Afonso and R. Strauch, February 2004.

304 "Equilibrium unemployment, job flows and inflation dynamics" by A. Trigari, February 2004.

305 "A structural common factor approach to core inflation estimation and forecasting" by C. Morana, February 2004.

306 "A markup model of inflation for the euro area” by C. Bowdler and E. S. Jansen, February 2004.

307 "Budgetary forecasts in Europe - the track record of stability and convergence programmes" by R. Strauch, M. Hallerberg and J. von Hagen, February 2004.

308 "International risk-sharing and the transmission of productivity shocks" by G. Corsetti, L. Dedola and S. Leduc, February 2004.

309 "Monetary policy shocks in the euro area and global liquidity spillovers" by J. Sousa and A. Zaghini, February 2004.

310 "International equity flows and returns: A quantitative equilibrium approach" by R. Albuquerque, G. H. Bauer and M. Schneider, February 2004.

311 "Current account dynamics in OECD and EU acceding countries - an intertemporal approach" by M. Bussière, M. Fratzscher and G. Müller, February 2004. 
312 "Similarities and convergence in G-7 cycles" by F. Canova, M. Ciccarelli and E. Ortega, February 2004.

313 "The high-yield segment of the corporate bond market: a diffusion modelling approach for the United States, the United Kingdom and the euro area" by G. de Bondt and D. Marqués, February 2004.

314 "Exchange rate risks and asset prices in a small open economy" by A. Derviz, March 2004.

315 "Option-implied asymmetries in bond market expectations around monetary policy actions of the ECB" by S. Vähämaa, March 2004.

316 "Cooperation in international banking supervision" by C. Holthausen and T. Rønde, March 2004.

317 "Fiscal policy and inflation volatility" by P. C. Rother, March 2004.

318 "Gross job flows and institutions in Europe" by R. Gómez-Salvador, J. Messina and G. Vallanti, March 2004.

319 "Risk sharing through financial markets with endogenous enforcement of trades" by T. V. Köppl, March 2004.

320 "Institutions and service employment: a panel study for OECD countries" by J. Messina, March 2004.

321 "Frequency domain principal components estimation of fractionally cointegrated processes" by C. Morana, March 2004.

322 "Modelling inflation in the euro area" by E. S. Jansen, March 2004.

323 "On the indeterminacy of New-Keynesian economics" by A. Beyer and R. E. A. Farmer, March 2004.

324 “Fundamentals and joint currency crises" by P. Hartmann, S. Straetmans and C. G. de Vries, March 2004.

325 "What are the spill-overs from fiscal shocks in Europe? An empirical analysis" by M. Giuliodori and R. Beetsma, March 2004.

326 "The great depression and the Friedman-Schwartz hypothesis" by L. Christiano, R. Motto and M. Rostagno, March 2004.

327 "Diversification in euro area stock markets: country versus industry" by G. A. Moerman, April 2004.

328 "Non-fundamental exchange rate volatility and welfare" by R. Straub and I. Tchakarov, April 2004.

329 "On the determinants of euro area FDI to the United States: the knowledge-capital-Tobin's Q framework, by R. A. De Santis, R. Anderton and A. Hijzen, April 2004.

330 "The demand for euro area currencies: past, present and future" by B. Fischer, P. Köhler and F. Seitz, April 2004.

33I "How frequently do prices change? evidence based on the micro data underlying the Belgian CPI" by

L. Aucremanne and E. Dhyne, April 2004.

332 "Stylised features of price setting behaviour in Portugal: 1992-200I" by M. Dias, D. Dias and P. D. Neves, April 2004. 
333 "The pricing behaviour of Italian firms: New survey evidence on price stickiness" by S. Fabiani, A. Gattulli and R. Sabbatini, April 2004.

334 "Is inflation persistence intrinsic in industrial economies?" by A. T. Levin and J. M. Piger, April 2004.

335 “Has eura-area inflation persistence changed over time?" by G. O’Reilly and K. Whelan, April 2004.

336 "The great inflation of the 1970s" by F. Collard and H. Dellas, April 2004.

337 "The decline of activist stabilization policy: Natural rate misperceptions, learning and expectations" by A. Orphanides and J. C. Williams, April 2004.

338 “The optimal degree of discretion in monetary policy” by S. Athey, A. Atkeson and P. J. Kehoe, April 2004.

339 “Understanding the effects of government spending on consumption” by J. Galí, J. D. López-Salido and J. Vallés, April 2004.

340 "Indeterminacy with inflation-forecast-based rules in a two-bloc model” by N. Batini, P.Levine and J. Pearlman, April 2004.

34I "Benefits and spillovers of greater competition in Europe: A macroeconomic assessment" by T. Bayoumi, D. Laxton and P. Pesenti, April 2004.

342 "Equal size, equal role? Interest rate interdependence between the euro area and the United States" by M. Ehrmann and M. Fratzscher, April 2004.

343 "Monetary discretion, pricing complementarity and dynamic multiple equilibria” by R. G. King and A. L. Wolman, April 2004.

344 "Ramsey monetary policy and international relative prices" by E. Faia and T. Monacelli, April 2004.

345 “Optimal monetary and fiscal policy: A linear-quadratic approach” by P. Benigno and M. Woodford, April 2004.

346 "Perpetual youth and endogenous labour supply: a problem and a possible solution" by G. Ascari and N. Rankin, April 2004.

347 'Firms' investment decisions in response to demand and price uncertainty" by C. Fuss and P. Vermeulen, April 2004.

348 “Financial openness and growth: Short-run gain, long-run pain?” by M. Fratzscher and M. Bussiere, April 2004. 
